\title{
POYI! Bamana jeli music, Mali and the blues
}

Lucy Durán*

Department of the Languages and Cultures of Africa, SOAS, London, UK

(Received 2 April 2013; final version received 2 April 2013)

The search for the African roots of the blues has long been a subject of fascination to writers, scholars and musicians, with Mali taking an increasingly central role in the popular imagination as the missing link in the blues' DNA. Many Malian artists have found their music being labelled by journalists and record companies with such tags as 'Mali Blues', 'Desert Blues' and 'Bambara Blues', in recognition of the strong stylistic similarities with the Delta Blues in particular. But which way around did the influences travel? A crucial piece to the puzzle is a Bamana jeli (griot) song called 'Poyi', which, according to oral tradition, may have been the last tune that war captives of the empire of Segu (1712-1861) heard, before being taken into slavery.

This article explores the complex trajectory of the trans-Atlantic conversations between the blues and Mali, by focusing on one musical tradition that has so far been ignored in scholarly studies of both blues and Mande music - that of the Bamana ('Bambara') griots from Segu in the middle Niger valley, with their trademark lute, the ngóniba. Drawing both on extensive academic research carried out on Mande music, and on long practical experience of working as music producer of Mande artists, it argues that Bamana music could well be a strong contender for the 'roots of the blues'.

Keywords: Malian blues; Mande music; roots of the blues

\section{Introduction}

On a late afternoon in February 2006 in Garana, a village deep in the countryside of Segou ${ }^{1}$ province (Mali), a local crowd was gathered in the courtyard of a family of Bamana jeliw (hereditary musicians or 'griots' of the Bamana people ${ }^{2}$ ). They were hosting some festivities to welcome a renowned marabout (Muslim cleric) to the village. Seated in the centre of the courtyard was the head of the jeli household, the veteran female singer Yakaré Damba, together with several of her sons, ranging in age from their 20 s to late 40 s. All were exceptionally talented performers of the ngòni, a West African lute with a wooden resonator and skin sound table. Around the imposing figure of the matriarch were many of her grandchildren, some barely old enough to walk, some in their late teens - all budding singers, dancers and drummers in this intensely musical family.

Yakaré's son Bassekou Kouyaté was the family's most celebrated artist. He had been touring and recording with some of Mali's most prominent musicians since the early 1990s, and was known for his innovative approach to the centuries' old music of the Bamana griots with which he had grown up. ${ }^{3}$ One such innovation was to attach the ngòni to a strap slung around his shoulder, guitar style - which was how he was holding the instrument that day. By contrast, his elder brother, Modibo Kouyaté, played in the more traditional way, seated on the ground, his right leg hooked over the ngòni (see Figures 1 and 2). The two had been raised together in Garana

\footnotetext{
*Email: 1d@soas.ac.uk
} 


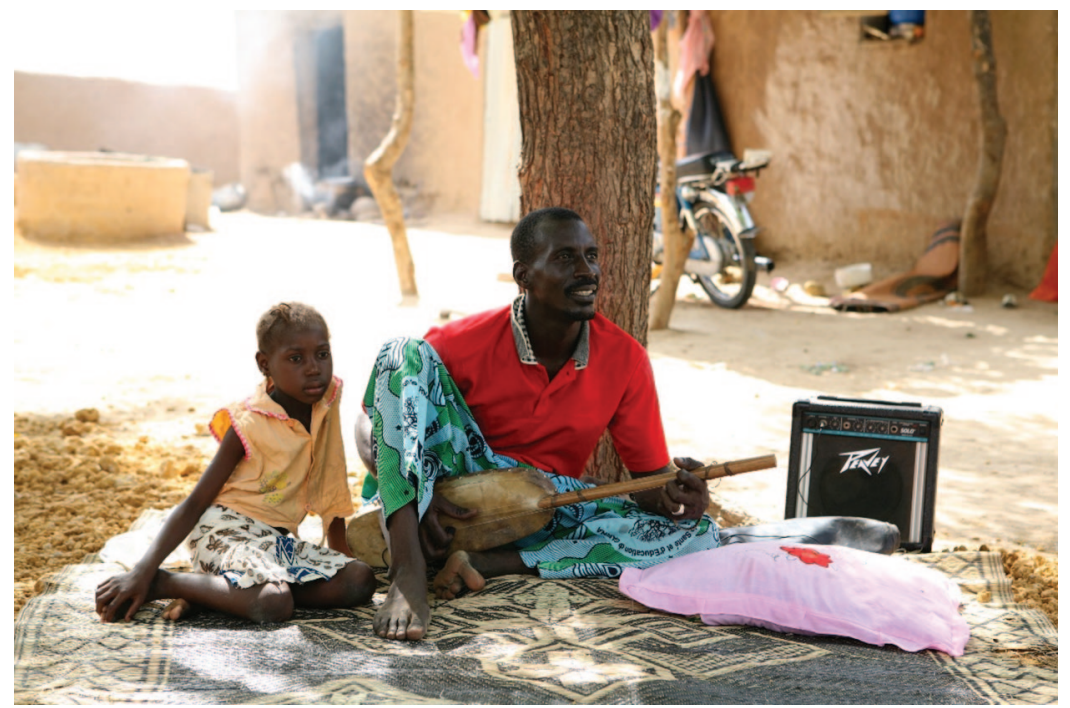

Figure 1. Modibo Kouyaté, older brother of Bassekou Kouyaté, plays the ngòniba. His daughter Bintou Kouyaté, a budding singer, sits with him, at home in Garana, Segou province, 2008.

Source: Photo by Thomas Dorn, by permission.

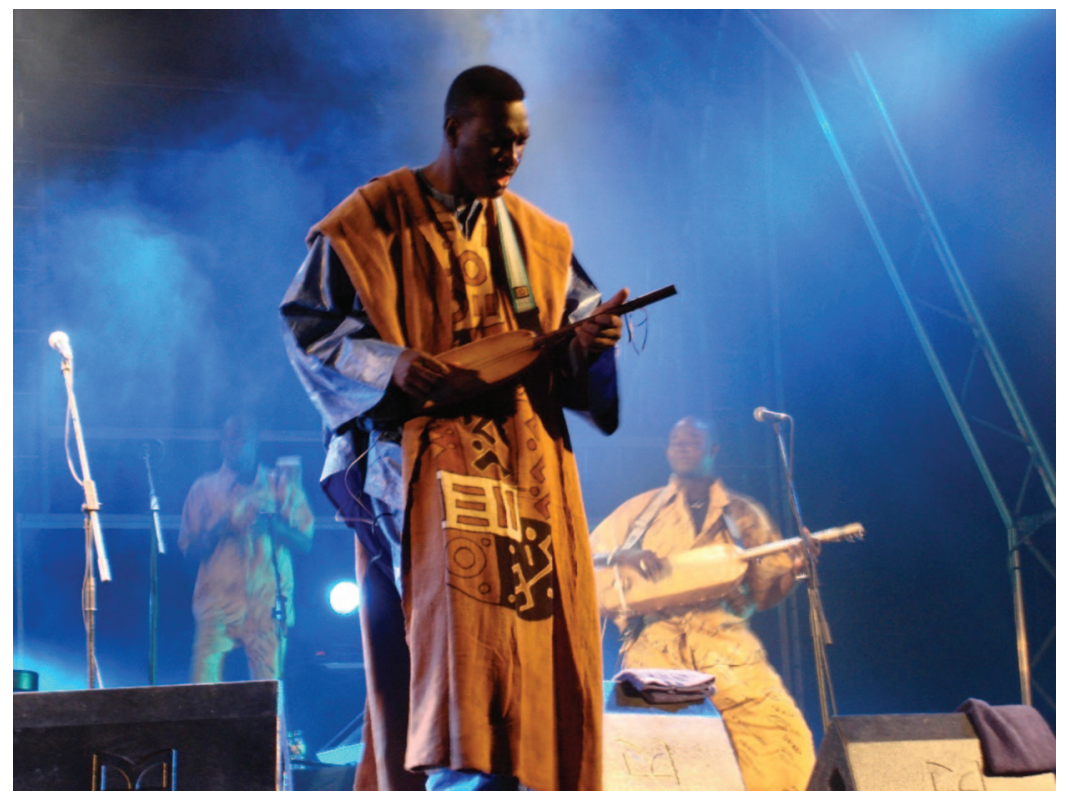

Figure 2. Bassekou Kouyaté on stage with his band in Lisbon, 2007. One of his first performances with his band Ngoniba following the release of their first album, Sеgu Blue. Note the straps that hold the instruments. Source:

(along with 11 other brothers and sisters), but Modibo stayed in the village, while Bassekou moved to Bamako in his late teens.

Garana lies in the heart of the historical region known as Dò. In the epic tradition of the Mande jeliw, the Mande Empire was founded by Sunjata Keita in c. 1235, and his mother, Sogolon Kone, was from Dò. Just $2 \mathrm{~km}$ away from Garana, at the top of a small hill in the middle of an arable 
field, is the supposed grave of Sunjata Keita's aunt, Dò Kamissa, the 'buffalo woman'. This littleknown, and rarely visited, spot plays a significant role in the imaginary of Bamana jeliw, as it was from her lineage that Sunjata was believed to have derived his esoteric strength, with which he led the Mande to power ${ }^{4}$ (See Figure 3).

Like many of the surrounding villages in this part of Mali, the middle Niger valley, Garana has a mixed population consisting of four main ethnicities - the Bamana who are the farmers, the Fulbe who are the pastoralists, the Bozo who are the fishermen, and the Soninke who are the merchants and Muslim clerics, along with the Jokarame (a sedentary branch of the Fulbe). For the day's festivities, each one of these had provided their own drummers and singers to represent their communities and to entertain the crowd. Megaphones connected to a rudimentary sound system had been mounted around the courtyard, blaring out the music. When the drumming and dancing finished, the village schoolteacher gave a formal welcome speech. Then it was time for the Kouyaté family to perform the songs for which they were known throughout the region: Bamana jeli (griot) music. Most of their repertoire dates from the time of the Segu Empire (c. 1712-1861) ${ }^{5}$ (Figure 4).

Bamana jeli music shares some elements with other, better known and more studied, forms of Mande music, ${ }^{6}$ but it has also many features that set it apart. The repertoire is made up of a number of songs that tell the stories of Segu's rulers and warriors, typically accompanied on the ngoniba, a large four-string version of the lute, the preferred instrument of Segu's rulers (as described later on in this article). The songs are characterized by pentatonic scales, 6/8 rhythm and slow tempo. Combined with the timbre of the ngòni, derived from fingering techniques that include slides, pulls, hammers and vibrato on the strings, ${ }^{7}$ Bamana jeli music is at times heavily redolent of the blues.

One piece in particular, 'Poyi', stood out that day as a blues 'dead ringer' - especially the way it was played by Bassekou Kouyaté. I was in Garana at the time, researching the Bamana repertoire for a recording project with Bassekou. ${ }^{8}$ I was already familiar with several of the best-known Bamana songs such as 'Da Monzon' and 'Bakari Jan', but 'Poyi' was new to me. Perhaps I had

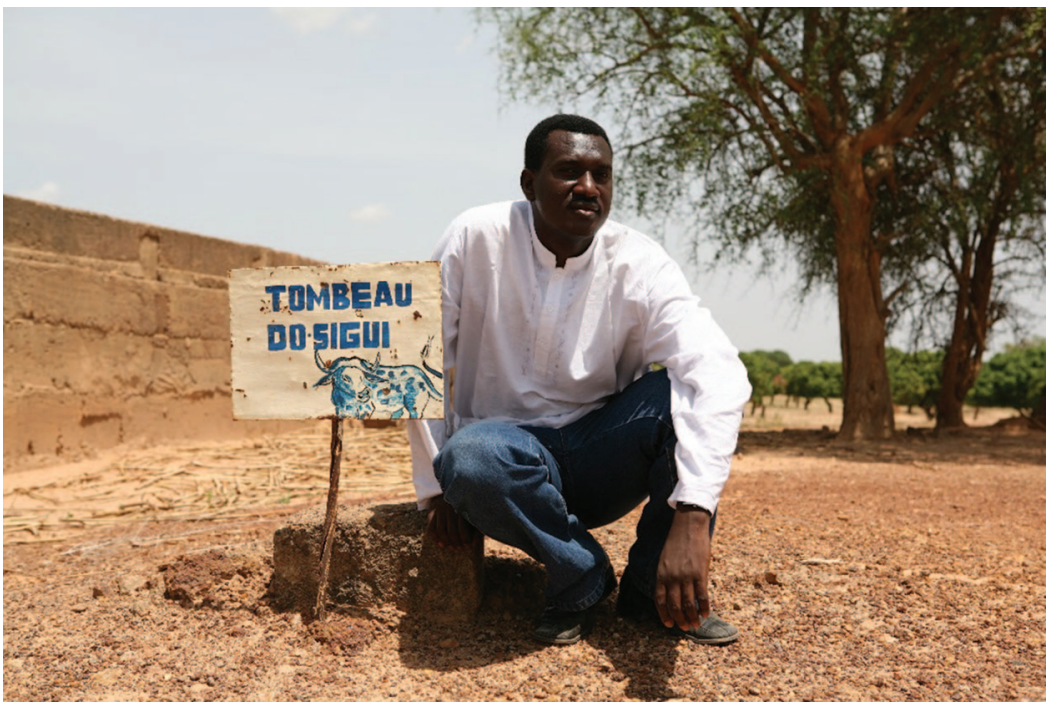

Figure 3. Bassekou Kouyaté at the spot marking the supposed grave of Dò Kamissa (the buffalo woman), aunt of Sunjata Keita, who founded the Mali Empire in 1235. 


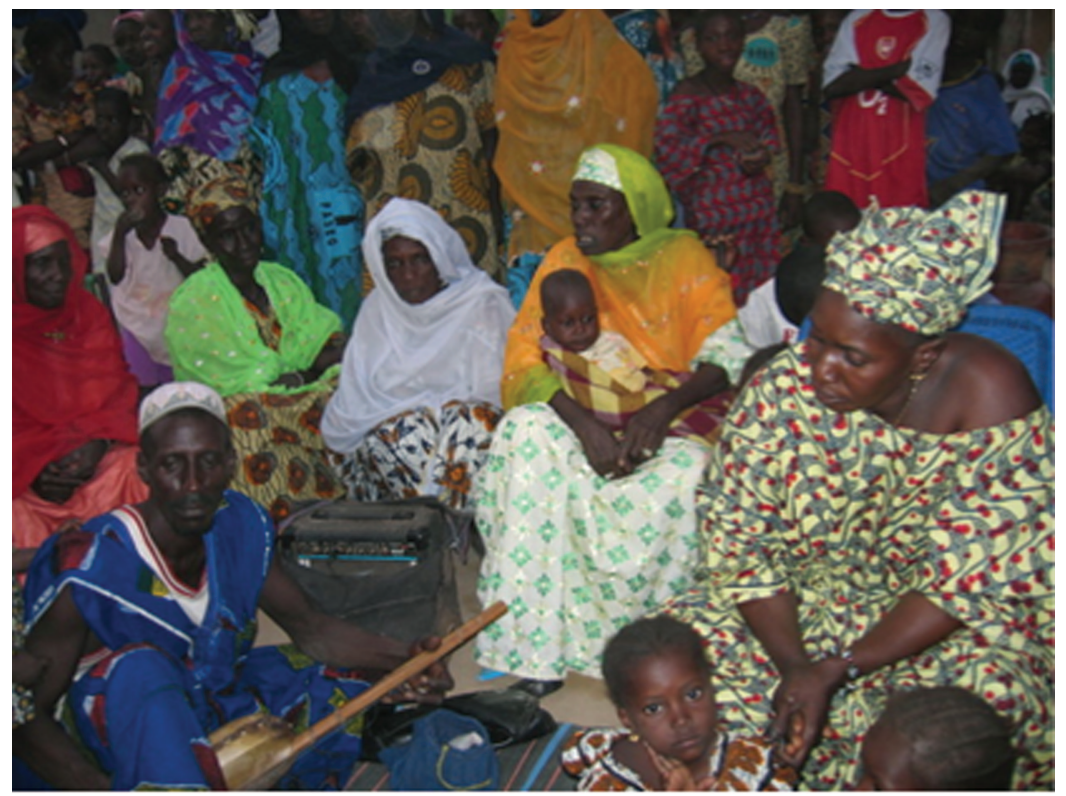

Figure 4. Modibo Kouyaté playing the ngòniba, through a small amplifier, surrounded by his family: his mother, the singer Yakaré Damba (wearing an orange and green scarf) and his sister Oumou Kouyaté (far right).

Source: Garana (2006).

heard 'Poyi' before but had failed to recognize it, since it is more of a template accompaniment than a specific song, much in the way that the blues is. While his older brother Modibo played a slow, two-bar melody in 6/8 time on the large ngòniba, Bassekou gradually added variations on a smaller ngòni, some of which sounded distinctly bluesy, at times reminiscent of the kinds of guitar riffs one might hear on a John Lee Hooker track. ${ }^{9}$

That evening when the festivities were over, I asked the two brothers to tell me more about 'Poyi'. Bassekou explained that it was an old, very traditional piece, which had several regional variants. He had taken his father's version and modified it in his own way - a common enough process by which Mande jeli pieces evolve through time and the oral tradition. Bassekou's way of playing 'Poyi' reflected his contact with blues musicians on stages and in studios around the world. Nevertheless, his upbringing in a remote village as the son of a knowledgeable and distinguished jeli family had provided him with a solid grounding in local oral narrative.

From Bassekou's description it emerged that unlike most of the Mande jeli repertoire, 'Poyi' is not connected with any one historical person or song. ${ }^{10}$ Instead it is an accompaniment, over which male jeliw would improvise spoken praises for those who have demonstrated great bravery and strength. It could also be played as an instrumental, which is unusual in the Mande repertoire. 'Poyi', added Modibo (who had never heard of the blues), was a term to signify bravery on the battlefield, at the time of the Segu Empire. It was the tune to which nobles swore an oath. It also had grim associations with the battlefield.

Poyi is the original Bamana blues. We were taught it by our father Moustapha Kouyaté who was a great ngòni player, and his father before him. He never even heard of the blues, but when he played Poyi, it was the blues. Poyi means to kill people; it means to shed blood. It was considered better to capture your opponent alive than to kill him. Would they ever come back alive to their homes and family - or would they lie dead in the battlefield, food for vultures, or be captured and enslaved? 
After the battle, all those captured alive had to line up, and the jeli would play Poyi... One after the other each would be asked, 'do you want to go into slavery?' If he says yes, he passes out of the line and he belongs to his captor. If he says no, he has to stand still, and his head is chopped off. (Bassekou Kouyaté, Personal communication, Garana, 2006)

There is plenty of gore in the Bamana epic tradition (see, for example, the vivid description of a bloody massacre by hatchetmen of Bamana elders after the death of Monzon; Conrad 1999, 186187). Yet the Kouyaté brothers' account of how 'Poyi' was linked to the precise moment when captured warriors had to choose between shameful life in slavery or honour in death, ${ }^{11}$ opened up new perspectives on the so-far undocumented connections between the blues and Bamana music. It raised the question: how significant was the context in which such music was played, if it was the last piece to be played to warriors before they went to battle? What effect would such an association with warfare, bloodshed and indeed esoteric power have on the minds of captives, some of whom might have been shipped across the Atlantic?

This article attempts to address some of these questions. A major part of the discussion is devoted to a long-overdue ethnography of Bamana jeli music, giving descriptions of its historical and cultural context, its musical and lyrical features, its main instrument, the ngoniba, and its repertoires, in order to better assess their place in the quest for the roots of the blues. The article draws on extensive research conducted by the author with Mande jeliw over many years in Mali. The family of Bassekou Kouyaté in Garana, who represent an old and authoritative oral tradition, have been a particularly important source of information on the Bamana repertoire, but many other musicians have also been consulted on the topic in both Segou and Bamako and in the diaspora. ${ }^{12}$

The discussion ends with a focus on 'Poyi', a tune that has been little reported and for which there are few recordings. Yet there is enough evidence from oral tradition, documentary literature and a few extant recordings to suggest that it was once a powerful signifier of core Bamana values. Ali Farka Touré, the leading figure in Mali's 'desert blues', cited 'Poyi' as a kind of proto-blues: 'I have always said the word blues has no significance here in Africa ... if there's a need for a label, there's no reason why the Americans shouldn't call it the blues. But if I say ... Seygalare, ... or Ndoondo, or Mbowdi, or Poyi! Everyone here knows what that is.'13

Writing about uprooted populations on the borderlands of South Africa, Mozambique and Swaziland, Angela Impey observes that: 'sound, song, and the effect of music-making represent a much under-utilised historical research resource, particularly in contexts of spatial and social rupture' (Impey 2008, 33). 'Poyi' may well be such a resource, a piece of musical archaeology surviving in the oral tradition, which has a bearing on the story of Mali and the blues.

The quest for specific African sources of African-American musical genres is highly problematic (see Kubik 1999, 22-23). In a 2007 interview for the American radio programme Afropop Worldwide, Kubik, whose book Africa and the Blues (1999) is the most comprehensive study to date, emphasized the futility of looking for African roots of the blues.

In African and African-American history as elsewhere in the world we have to operate from sources: written sources, oral sources, recorded sources, if possible, archaeological sources. Where there are no sources, there can be no safe conclusions. 'Roots' is too vague to be used beyond casual statements that such and such tradition is based on something, somewhere. For example all the talk about roots of the blues in Mali is just enough to satisfy the public's need for wild imagination. But we want to know which traditions, by whom in Mali or elsewhere, and in which time period - late 18th century? - were relevant as a background for the rise of blues in the US a century later. Popular formulations such as 'From Mali to Mississippi' are anathema to historical studies.

(Gerhard Kubik, interview with Banning Eyre on Afropop Worldwide, 2007, PBS radio) ${ }^{14}$

In an attempt to move beyond the public's 'wild imagination', this article seeks to provide some answers to Kubik's three questions, as follows: 
(1) 'which traditions?' This article argues that Bamana jeli music is one tradition that has so far been overlooked as a music which might well have fed into the early rural blues, and, before that, slave banjo music. Bamana music belongs to a wider regional style in central Mali, overlapping with other neighbouring cultures such as those of the Fulbe and Soninke, but it may have been the conduit by which such musical traits crossed the Atlantic with the slave trade;

(2) 'played by whom in Mali?' I suggest that the answer to this is the Bamana jeliw, with tunes such as 'Poyi';

(3) 'during which time period?' This question can be answered at a broad level by citing the Bamana Segu Empire during the eighteenth century, a time of intensive slave trade, to which the empire certainly contributed. Not only did the Bamana Segu Empire thrive on slavery, but it was ruled by former war captives (the Diarra lineage), from 1766 to 1861 (Conrad 1990). But perhaps we can further narrow down the 'which time' question, and even suggest a likely specific context in which this possible root of the blues would have been played: that is, precisely around the many battles that were an intrinsic feature of life in Bamana Segu and that engendered vast numbers of slaves, some of whom were sent across the Atlantic.

While the epic recitations by Bamana jeliw with their vivid stories of Segu's rulers (faamaw) have been well documented from the point of view of their texts (Kesteloot, Courlander, Dumestre, Conrad), the music, which is equally steeped in the history and ethos of the region, has still not been researched. Bamana music is not included in Charry's otherwise comprehensive study of Mande music, which focuses on Maninka and Mandinka traditions, though he does acknowledge that 'the reign of the Bamana of Segu in the seventeenth and eighteenth centuries is an important source of pieces for Malian musicians' (Charry 2000a, 150). In addition, there are very few internationally available recordings either of Bamana music or of the ngoniba, its emblematic instrument. This general lack of source material no doubt explains why Bamana music has been omitted in studies of the possible African antecedents of the blues. It is only mentioned very briefly in Kubik's book Africa and the Blues (1999), which betrays a general lack of information about the styles from the middle Niger valley. Yet Kubik's instinct is to look for clues in precisely this region, referring to the music of Mali's griots as one 'likely candidate for early models that were still remembered by African Americans in the late eighteenth and early nineteenth century, eventually becoming a factor in the development of the blues' (Kubik 1999, 46). Kubik asks 'how such a "memory" could have survived until the end of the nineteenth century' (Kubik 1999, 46, italics in original), postulating that 'we are at least eighty years too late for reconstructing protoblues forms. On the other hand' he adds, 'the absence of written sources testifying to such memory does not present a puzzle' (Kubik 1999, 46).

'Poyi' is perhaps one piece of that puzzle of memory and musical survival - from the other side of the Atlantic (Figure 5).

\section{The search for the roots of the blues}

The search for the African roots of the blues has long been a subject of fascination to blues and African music scholars (Charters, Oliver, Evans, Kubik, Coolen), as well as to American musicians of all sorts from blues and jazz to banjo players (too numerous to mention here), and most recently film makers (for example, Scorsese's Feel Like Going Home, 2003).

The Malian singer and guitarist Ali Farka Touré was the first to draw international awareness to the similarities between traditional genres of Mali's northern desert and the blues, resulting in the label 'desert blues', coined in the early 1990s. His Grammy-winning album, Talkin' Timbuktu, 

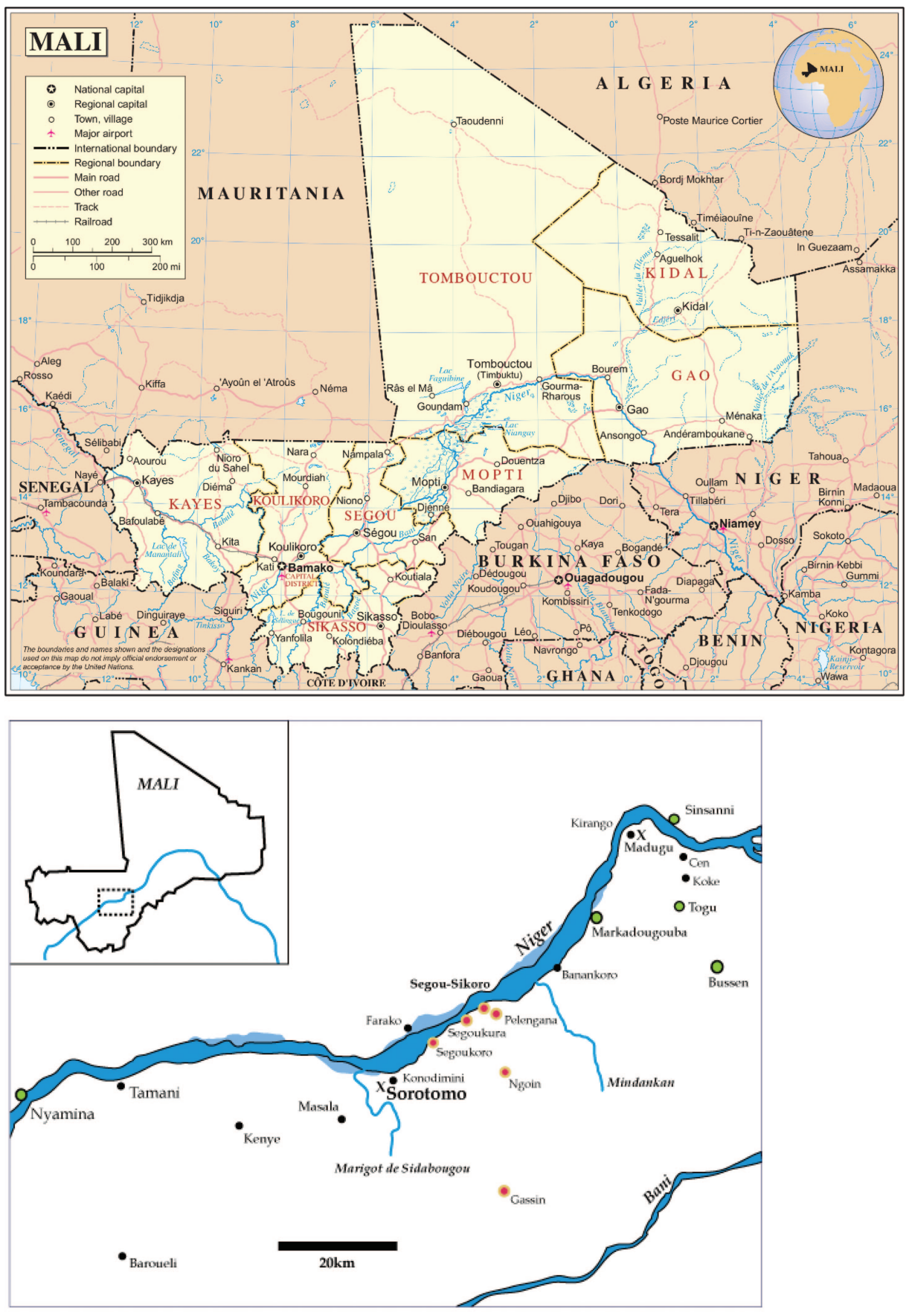

Key: - Modern Settlements X Ruins

- Former Capitals of Segou

O Historic Marka Towns

Figure 5. (a) Map of Mali showing Segou province, Mali's fourth region.

Source: http://commons.wikimedia.org/wiki/File:Un-mali.png; (b) Map of Segou region. Garana is 2 km east of Tamani.

Source: Macdonald et al. (2011). 
in which he collaborated with American guitarist Ry Cooder, captured the public imagination, and won him the epithet 'king of the desert blues'. Touré himself rejected such descriptions, however. He refuted the influence of the blues on his music, claiming that it was the other way around. In fact, the excessive interest of Western journalists in his blues connection irritated Touré. He would often joke that, for him, blues meant doctors, because doctors in Mali wore a blue uniform (personal communication, Nick Gold 2012).

Touré was a farmer and not a griot - a guitarist and singer whose connection with music came from his grandmother, Kounandi Samba, a medium of the river spirits (Gibbal 1994, 68; Durán 1996). He was inspired by the ngòni among other traditional instruments of the Niger valley, and indeed his early recordings often featured the ngòni or similar lutes played by griots from other ethnicities, such as gambare played by Barou Sambarou, a Soninke, and the hoddu, played by Nassourou Saré, a Fulani.

Kubik, who dedicates a large part of his Chapter 12, 'Return to the western Sudan' to a discussion of Touré, finds his music 'only vaguely related to any type of blues' (Kubik 1999, 194), and questions whether Touré's 'personal synthesis could be used to confirm pre-twentieth century historical connections [with the blues]' (Kubik 1999, 196). I would argue that there is only one way of doing so, which is to look at the local styles and songs that inspired him, rather than seeing it as a 'blues derivative'. ${ }^{15}$ Touré drew on a number of Malian styles; his favourites were the ones from his region, the bend of the Niger and the middle Niger valley.

Some decades before Touré put Mali on the musical map of the blues, Senegambia (particularly Wolof music) was considered a primary source of the blues, first suggested by David Ames (Ames 1955). This argument was developed by Oliver in his pioneering book Savannah Syncopators $(1970,43-50)$, and then echoed by Charters (1974, 1981) Coolen (1982, 1984, 1991), and others. As Kubik points out, the enormous success of Alex Haley's book and TV series Roots in the late 1970s and early 1980s, which places the Gambia at the centre of the story, certainly stimulated the African-American imagination (Kubik 1999, 188). Senegambia was an important source of plantation slaves in the Deep South (Coolen 1991). There are undeniable resemblances between blues guitar fingering styles and the thumb and finger interlocked plucking techniques on the Mandinka kora (Charry 2000a, 178-189). Banjo enthusiasts have also put forward other Senegambian string instruments, such as the Jola long-necked lute called akonting, as possible antecedents to the blues, ${ }^{16}$ and this connection has been explored most recently by the work of such banjo players as Bela Fleck on his 2010 Grammy awarded album, Throw Down Your Heart.

The lack of research on music from the middle Niger valley has, however, resulted in too narrow a focus on particular regional traditions of savannah West Africa without setting them in the wider context. For example, Coolen suggests the fodet, a term used by Wolof xalam players for both tunings and generic accompaniments, as a kind of template for the blues. While not wrong, fodet as a musical concept cannot be attributed solely to the Wolof, since similar concepts are shared by griots of neighbouring peoples all the way across the middle Niger valley. Also, there is much oral evidence to show that many Wolof xalamkats trace their ancestry to the Manden (the heartland of Mande culture in present-day western Mali and eastern Guinea), and a good part of their repertoire consists of well-known Mande jeli tunes like 'Manga Yira', 'Alfa Yaya', 'Tutu Jara' and 'Sunjata'; they even sing some of the choruses in Maninka, not in their own language, Wolof (see Charry 2000, 164; Duran 1981a).

Kubik is sceptical about arguments for the Senegambia, and instead gives

stronger weight to the central Sudanic region as one core area of provenance of some of the rural blues' most characteristic traits: the region from Mali across northern Ghana and northern Nigeria into northern and central Cameroon, rather than the westernmost geographical Sudan (Senegal, 
The Gambia). Other possible core areas include northern Guinea and the Sahel zone from Mali into Mauritania. (Kubik 1999, 69-70)

It is well documented that captives from Segu were sent across the Atlantic, though not in large numbers.

Curtin estimated that 80 percent of the total slave exports to the New World were transported between 1710 and 1850, or roughly during the entire era of the Segu Bambara state. Slaves from Segu destined for the Atlantic trade were probably sent to Senegambia and Sierra Leone. Slaves from these two regions accounted for only 10-15 percent of the total slave exports from 1701 to 1867 and Bambara slaves constituted only a fraction of this total. (Roberts 1987, 17-18)

The Scots explorer Mungo Park attests to the common practice of slavery in his account of his travels through the Mande countryside in 1796. His Chapter 22 is an interesting first-hand account of the various ways in which people became slaves, mainly warfare but also insolvency. In his diary entry for 18 July 1796, he writes 'I was met by a coffle of slaves, about seventy in number, coming from Sego [sic]' (Park 1797/1983). There are numerous other sightings of slaves throughout his travels.

This is significant because, as Kubik mentions, 'the story of the Bambara rice cultivators brought to Louisiana specifically for their technological expertize, has opened up new aspects of the fine meshes and economics of the slave trade and its huge networks into the interior of the west central Sudan' (Kubik 1999, 70). Carney's rich study of what she metaphorically calls 'black rice' shows that rice cultivation in the Western hemisphere was indeed introduced by Bamana slaves - mainly women, who to this day are the principal rice cultivators of the region - and 'depended upon the diffusion of an entire cultural system, from production to consumption' (Carney 2001, 165). Bamana slaves were 'central to understanding Louisiana history' (Eltis, Morgan, and Richardson 2007, 1332). The banjo, derived from West African lutes such as the ngòni, was one of the main instruments of Louisiana slaves (Conway 1995, 59).

In Kubik's chapter entitled 'Why did a west central Sudanic style cluster prevail in the blues?' he points on the one hand to the numbers of slaves to the New World from this region during the eighteenth century:

Senegal was part of the French slave trading network to Louisiana. Eventually, in the 19th century, some of the descendants of deportees from Senegal, Guinea, and Mali ended up on farms in Mississippi and elsewhere in the Deep South ... the names of ethnic groups from the geographical Sudan (as from other parts of Africa) were well remembered in new Orleans into the nineteenth century, though sometimes in the form of an interesting phonetic transfer into French. For example, Fulbe or 'Fula' became 'poulard' (fat chicken). (Kubik 1999, 96)

On the other hand, Kubik comments that 'in a group of people thrown together by the hazards of life, even one person is enough to transmit esoteric knowledge that might later become the property of a majority ... in culture contact situations it often happens that minorities win' (Kubik 1999, 98). Applying that argument to a piece of music, rather than a person, one could argue the case for 'Poyi' being recreated among slave communities in the Deep South, or, at very least, providing some key musical features that contributed to the foundation of the blues.

Rather than either Old World folkways or New World environments, we need to encompass both and become much more thoroughly Atlantic ... rather than frame the issue as solely one of transfers and conduits, we should also think of transformations and overlapping circuits. (Eltis, Morgan, and Richardson 2007, 1332)

Here I am not arguing that Bamana jeli music was directly transplanted via the slave trade to the Deep South, but that aspects of it stayed in the memory there during the eighteenth and nineteenth centuries, though perhaps relived in 'thoroughly Atlantic' ways (Figure 6). 


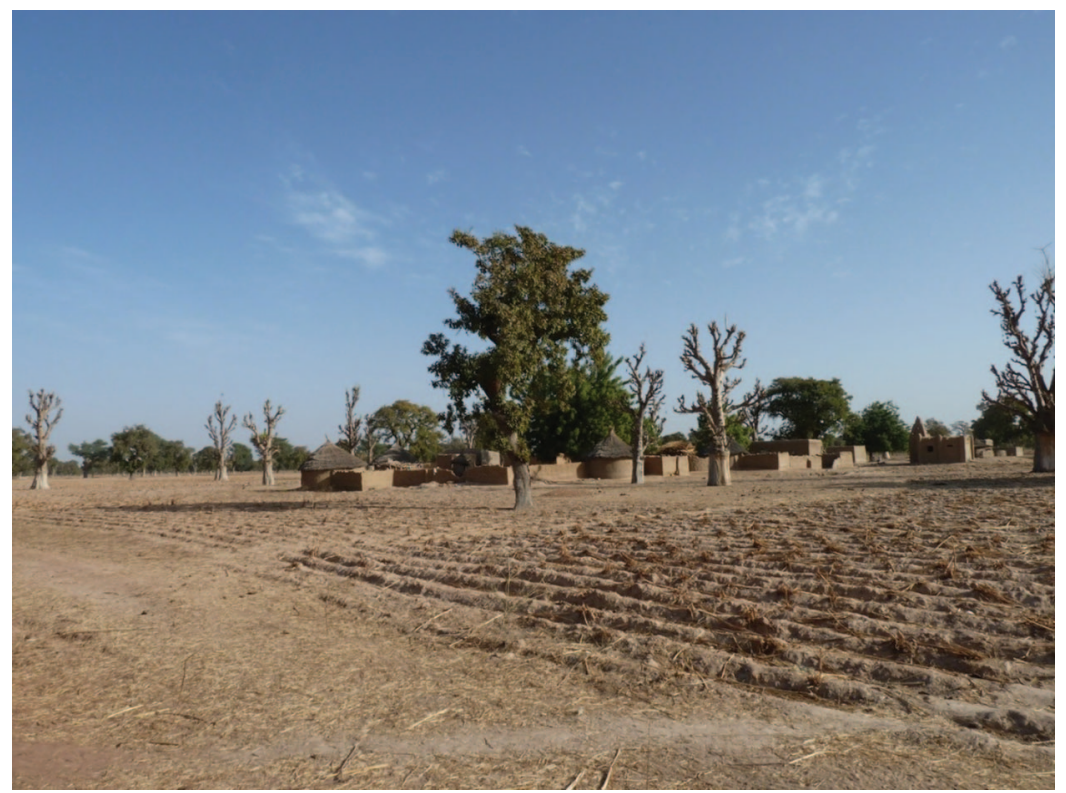

Figure 6. Segou countryside, near Garana, January 2011. The Bamana are farmers.

\section{'Flooding the ears of their hearts' ${ }^{17}$ : the Bamana of Segu}

A few salient facts about the Bamana are required here, as this provides the historical backdrop for how and why their music plays a part in the story of the blues. The Bamana are a Mande people in the middle Niger with a complex historical and ethnic makeup. They rose to power during one of Mali's last pre-colonial, and non-Islamic empires, known as Segu, 1712-1861. The name Bamana also refers to the language (known as Bamanan or Bamanankan) spoken throughout the south of the country, in some cases as a mother tongue by many who would not consider themselves ethnically Bamana; for example, the sedentary populations of Fulbe descent living in the regions of Wasulu and of Brigo in southwest Mali. Also, the term is often used generically to describe the Mande peoples of Mali in general - including the Maninka, the Wasulunke and Khassonke.

This section refers specifically to the Bamana of historical Segu, and the representation of 'Bamanaya' (what it is to be Bamana) in Bamana jeli song lyrics of today as represented in live performance and recordings. These songs are usually short and tend to be based on one episode or character in the story of Segu; it is extremely rare to hear full-length recitations ${ }^{18}$ such as those of Tayiru Banbera. Nevertheless, these songs, with their catchy pentatonic tunes and slow swinging 6/8 rhythms, keep alive the stories of the Segu era with their chivalry and gore.

'Segu is not a cosy story' comments Bassekou Kouyaté, drawing on oral traditions he heard as a child from both his father, Moustapha Kouyaté, and his maternal grandfather, one of Mali's most iconic jeliw of the post-independence era, Banzoumana Sissoko, 'the Old Lion' (c. 1890-1987). 'Love does not play a role in this. There was the cult of bravery. There was no fear of death, because if you were a coward, you couldn't marry, your family would reject you - so it was better to die.' (Bassekou Kouyaté, personal communication 2006).

Bamana jeli songs glorify animist belief and practice, such as the consuming of alcohol and the worship of shrines containing boliw (power objects). They tell of the customs around warfare, such as the feasts (maa nyènajè) held on the eve of battle outside the walls of the town to be 
aggressed, in which both sides participated, consuming large quantities of capalo, beer made from millet. ${ }^{19}$ They recount the exploits of the tonjòn, the dreaded slave army, who regularly looted villages and stole women, some of whom would be given to jeliw as wives. ${ }^{20}$ The tònjòn even had their own tònjòn dance, with humorously grotesque gestures designed to both amuse and terrify.

The history of Bamana Segu, described as 'a state of intrigue' (Conrad 1990), has been well documented. Much of what we know about this late pre-colonial period of Mali's history comes from the recitation of oral epics by Bamana jeliw, published in numerous transcriptions and translations. These focus on the esoteric power of one or two rulers (especially Da Monzon Diarra 1808-1827) and warriors (such as Bakari Jan Koné). The most detailed of these is a line-by-line transcription of performances by Tayiru Banbera (Conrad 1990; Banbera 1998) and constitutes 'one of the longest epics recorded in Africa' (Johnson, Hale, and Belcher 1997, 34). ${ }^{21}$

Conrad describes the Bamana of Segu as 'a society famous for maintaining its traditional cultural values and characterized by a wide range of secret ritual methods of tapping into spiritual sources of protection and power' (Conrad 1998, 1001). The Bamana resisted Islam in a series of confrontations with Fulbe armies until finally defeated in 1861 by Al-Hajj Umar Tall, a Fulani warrior cleric. ${ }^{22}$ Instead they had their own 'complex cosmogony that included a supreme creator and a pantheon of less deities ... the carrying out of the most serious of ... duties often required the use of a ritual object called a boli, which focused as a locus of sacrifice performed as a means of calling upon and influencing the vital spiritual force known as nyama' (Conrad 1990, 3).

Founded by Biton Mamary Coulibaly (1712-1755), the Bamana Empire was built on military conquest, with thousands of war captives that contributed to a vast and productive slave population. 'Warfare was an inseparable component of the political economy of the Middle Niger valley. Capturing slaves and conquering territory were its clearest expressions' 475 (Roberts 1987, 17). Segu's rulers, entitled faama, derived power from the tònjòn, a voluntary association comprised of men from all levels of society (noble to servile), which was Segu's army (Figure 7).

The death of Biton Coulibaly was followed by a period of anarchy (1757-1766), with successive rule by three former war captives until a fourth, Ngolo Diarra (1766-1787), founded a dynasty that lasted until 1861. His grandson Da Monzon Diarra (ruled 1808-1827) is the most celebrated of the Segu rulers, remembered and revered by Bamana jeliw for his power, wealth, ruthlessness and generosity with the jeliw.

Da was not a ruler to be trifled with; oral tradition has it that Da had only one eye, and therefore, no one in the land could pronounce the word 'one' without risk of being beheaded. The opening chorus of the song dedicated to Da Monzon says 'Ask Da! If a poor man even mentions the name of the faama [ruler], he'll be sold for the price of one barrel of beer', ${ }^{23}$ showing that he valued alcohol more than human life (Figure 8).

The linking of music with esoteric power (nyama) is common to all Mande jeli culture - and also the blues. ${ }^{24}$ Many jeliw express the view that the regional traditions of Bamana Segu are deeply infused with ngaraya or musical mastery, which in turn carries high levels of nyama. There is also the view expressed by some elder jeliw that it is more 'authentic', less commercial and has greater depth than the Maninka styles that were popularized in the capital from the late 1970s onwards (Duran 2007b).

The consumption of alcohol during the Segu era is one of the themes of the Segu repertoire. Tayiru Banbera, one of the great Bamana jeliw of the twentieth century, was a 'devout Muslim' (Conrad 1990, 7), but his descriptions are full of irreverent humour.

This is what the Bamana beer drinkers say: 


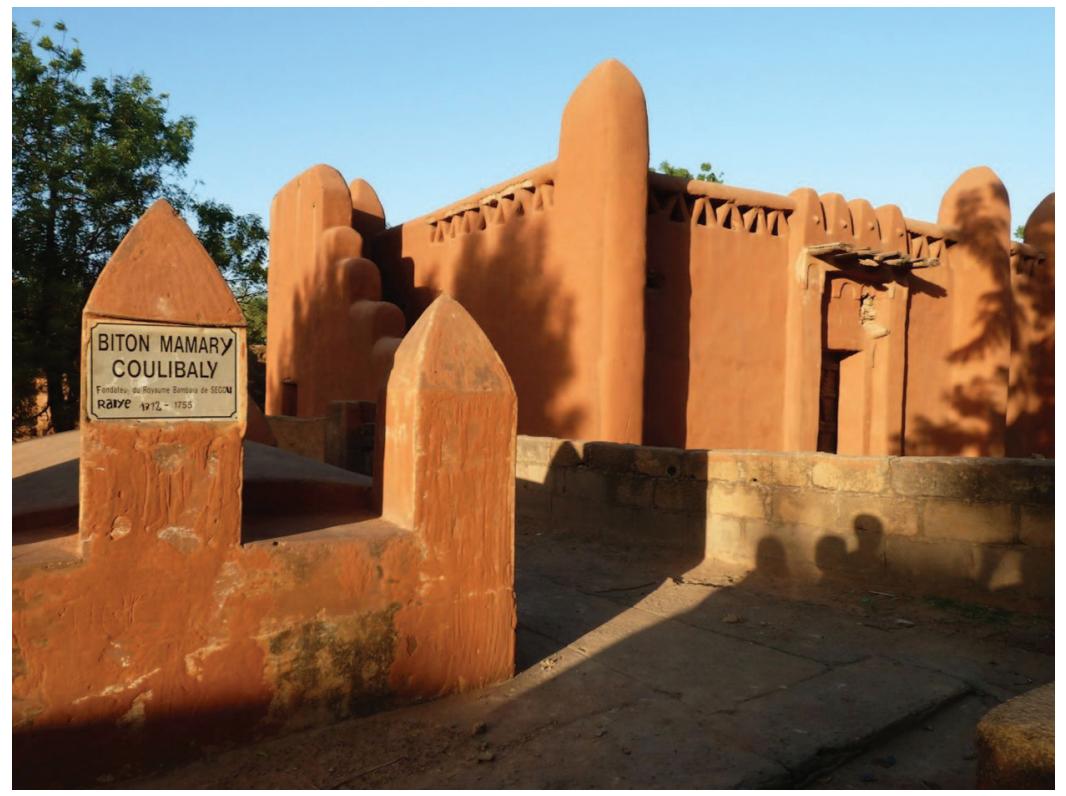

Figure 7. The tomb of Biton Mamary Coulibaly, founder of the Segu Empire, in Sekoro (old Segou), next to a recent reconstruction of his palace with its seven vestibules, 2011.

Source:

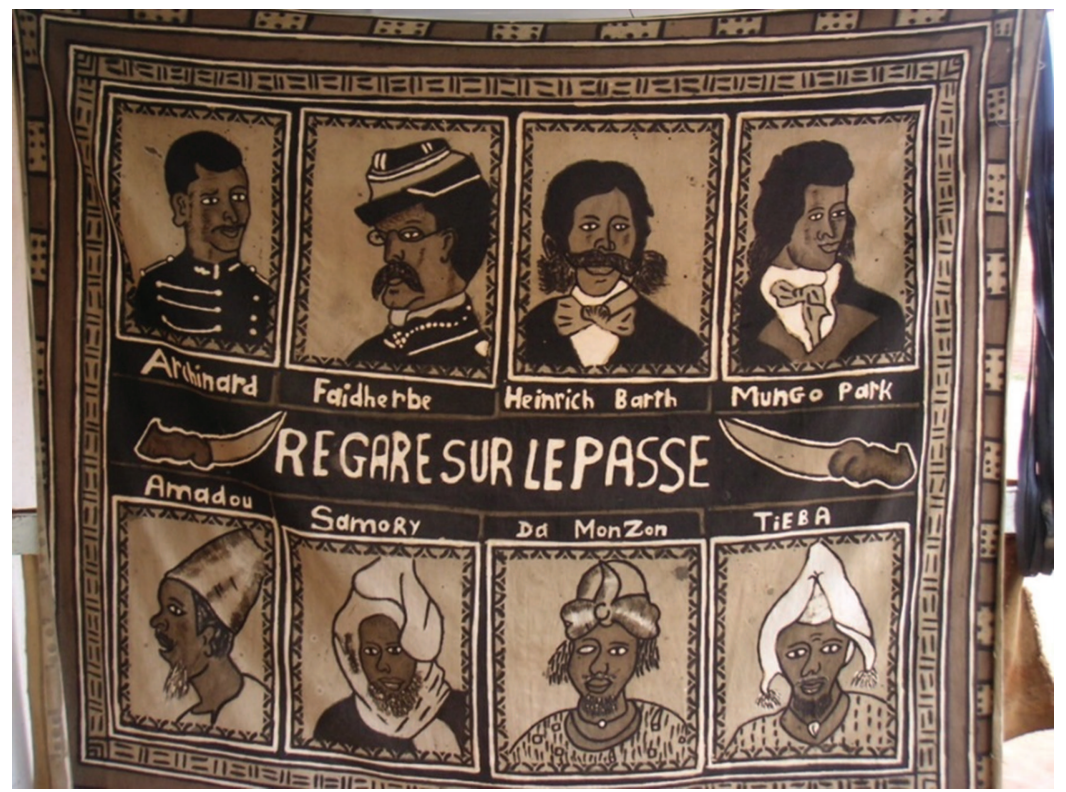

Figure 8. Mud-dye (bògòlan) cloth depicting some of the major characters connected with nineteenthcentury Malian history: (upper row) European travellers and colonizers, including Mungo Park and General Achinard; and (lower row) pre-colonial warlords and rulers, including (second from right) Da Monzon. Note his one eye.

Source: Segou market (2003). 
The marabout of the east says not to drink for it is bad.

The marabout of the west says there is no harm in drinking.

There are two different opinions.

But while the marabouts argue about the difference,

Let us drink and forget about the thirst of the world.

What they are talking about is lahara.

We have not been there

We know nothing about it.

We will not give up our habit to wait for that.

Let us get drunk.

The Bamana drink so much that they flood the ears of their hearts.

(Conrad 1990, 175: lines 3137-3148)

To this day, the Bamana are known for their relaxed attitude towards Islam, and there are (or were until the time of writing) many places that openly brew and sell capalo, even in Bamako - places where Bamana and other peoples from around Segou, mainly of the older generation, go to meet and socialize, and reaffirm their regional identities.

All this contributes to the people of Segou, or 'Segovians' as they are known locally, having a certain reputation in Mali. Tayiru Banbera recites:

everybody who comes to power in Mali,

if it is said that he comes from Segu,

he will be feared. (Conrad 1990, 128)

\section{And Conrad comments,}

regardless of where the person in power actually comes from, this expression labels him as shrewd, or even ruthless. It might be said, 'so-and-so's wife is from Segu', meaning she dominates her husband. Similarly, if it is said that someone gave you 'Segu porridge' ... it means they outwitted you at something. (Conrad 1990, 128)

In February 2006, as part of our preliminary research for his album, Bassekou took me to visit the tomb of Da Monzon, which is located in Banankoroba, a village a few kilometres east of Segou. It was a simple vaulted grave made of cement, located inside the courtyard of a house, under the custody of family whose surname - ironically - is Coulibaly. Bassekou, for whom Da Monzon symbolizes the essence of Bamanaya, took his ngòniba out of its case, knelt down by the grave and in a solemn fashion began playing Da Monzon's fasa (praise song), over which he declaimed:

I say now to my great grandfather's king - he was such a great warrior, right from the beginning to the end of his life, no-one trod on his foot. No one dared look him in the eye and say no. I praise him for all the great things he did for us jeliw. He used to give us cows, horses, slaves. He used to capture a village and give the whole village to one jeli. With Da Monzon, no jeli was ever hungry. That's what I praise him for. And he said two things to them. He said, 'When I die, my jeliw will leave, because no other king can support them like I did. And there will never be another good Bamana king after me. I will be the last.' And no other king was a true Bamana like he was. Being a true Bamana means never cheating with another man's wife. It also means giving one's word and never taking it back - if a Bamana says 'I will do this', he will do it. And a true Bamana will always be prepared to die for his honour ${ }^{25}$ (Figure 9)

In subsequent discussion, Bassekou explained that these were the kinds of words that Da Monzon would want to hear at his grave, even if he, Bassekou, as a man of the twenty-first century, abhorred the idea of slavery and warfare. 


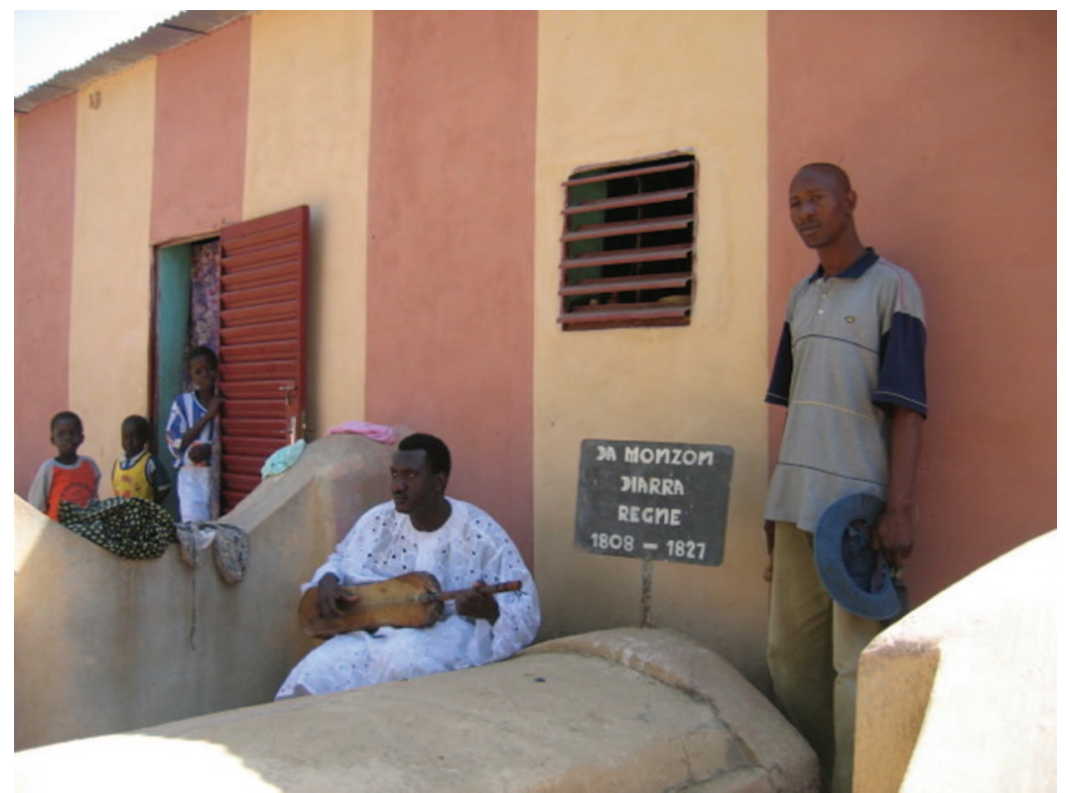

Figure 9. Bassekou Kouyaté plays the ngòniba at the grave of Da Monzon Diarra, ruler of Segu from 18081827.

Source: Banankoroba, Segou, 2006.

As we left the grave, I asked the custodian, Mr Coulibaly, how he felt about being entrusted with care of the grave of the Diara lineage, who had wrested power from the his own ancestor, Biton Mamary Coulibaly, founder of the Segu Empire. 'If Da Monzon had power, it's only because we the Coulibaly lineage lent it to him' was his reply.

The concept of betrayal (janfa) in Segu was specifically linked to the act of breaking one's word, or reneging on a mutual agreement (Dumestre 1979, 235). In the words of Tayiru Banbera:

If a noble swore an oath they would say 'I am serious',

It is the word of a noble.

They pledged their honour,

If a noble swore such an oath, that was all.

that was the end of it, that was enough.

If he swore to kill a man,

He would kill him.

(Conrad 1990, 63)

This is echoed in Frobenius' account of a series of heroic narratives entitled Pui, to which we return at the end of this article. In Pui, the jeli asks the ruler, 'how does one keep one's word, half or whole?' and the ruler replied, 'one keeps one's word whole completely ${ }^{26}$ (Frobenius 1921, 110). The implications of this are considerable, since, according to Bassekou Kouyaté, 'Poyi' was the tune to which a noble would swear to uphold his word (as discussed later).

The seizing of power from the Coulibaly lineage and the establishment of the Diarra rule by a captive had major consequences for social structure - and music - in the middle Niger valley. 'This was the first time [in the feudal societies of the western Soudan] that those who were 
noble by blood were supplanted by the power of arms ... it became possible for an individual to become noble, and for member of a caste or a slave to escape their status and become a respected warrior' (Kesteloot and Dumestre 1975, 10; my translation).

Tayiru Banbera recites

...those times were different from today.

If you could catch somebody, you could sell him.

If somebody could catch you, he would sell you.

There was no such thing as prison.

They never tied people up and beat them.

If you killed someone, it was all right.

But if somebody killed you, that was all right.

This is how the Bamana behaved.

They could do what they wanted.

(Conrad 1990, 194)

Thus, through the epic traditions and songs of Segu, we learn that it was a place where anyone could become a captive at any time, or, conversely, go from captive status to becoming a ruler. Might such stories not have had resonance with slaves taken from the region, infusing their memories of music in Segu with powerful emotional and psychological associations?

\section{Bamana jeli music - characteristics and repertoire}

According to Kubik, the 'west central Sudanic belt is the style world that presents the closest stylistic parallel from any part of Africa to what can be heard in the blues' (Kubik 1999, 63-64, but Bamana jeli music is not included in his discussion). What new evidence can this tradition throw on our understanding of the African sources of the blues? And why has it been overlooked to date?

The Bamana repertoire is inextricably connected with the region of Segou. Unlike other Mande jeli pieces from Mali, it has not migrated westwards into Senegambia (see Charry 2000a, 149) and therefore was omitted from the first public exposure to Mande music in the 1970 s. ${ }^{27}$ In fact, until the recent solo project of Bassekou Kouyaté and his quartet of ngònis, it was little known outside Mali. Bamana music has much more in common musically with the blues than the heptatonic styles of the Maninka and Mandinka, which are the dominant sounds of the southwest of Mali, upper Guinea, southern Senegal and Gambia.

'Bajuru' (or bajourou, using the French spelling), is one of the few heptatonic tunes in the Bamana repertoire, and virtually the only one that is also played by Maninka, Mandinka and Wolof griots, ${ }^{28}$ where it is better known by the name 'Tutu Jara' (or 'Toutou Diarra'). According to oral traditions in Senegambia and western Mali, 'Tutu Jara' originated in Segu, but it has either been Maninka-ized in its melodic features, or else, as some oral traditions suggest, it originated in the Mande heartland, but was 'captured' by the Bamana. ${ }^{29}$

Bamana jeli music ${ }^{30}$ belongs to the 'style-cluster' of the middle Niger valley, sharing musical characteristics with neighbouring peoples, the Soninke, Sonrai and Fulbe, who also have the lute as their principal instrument and have 'co-existed for centuries of cultural interchange, living in the region as distinct but overlapping cultures' (Kone 2000).

The instrument par excellence of the Bamana jeli is the ngòniba, the large lute (also known as bamanangòni), with four strings, as described in more detail later on.

Kubik identifies two main strands of west Sudanic traditions that might have contributed to the blues: 'ancient Negritic' and Islamic (Kubik 1999, 95). He outlines the following 
characteristics (amongst others) for rural blues from the Deep South, such as a primarily solo singing tradition; 'wavy intonation'; 'rather slow triple or swing tempos'; a relationship between the vocals and instrumental accompaniment of unison or heterophony, pentatonic vocal melodies; the use of string instruments, and the absence of percussion (Kubik 1999).

Pentatonic scales are a significant feature of Bamana jeli music. There are two main Bamana pentatonic scales, corresponding roughly to CDEGA (major pentatonic) (for example, as in the song 'Da Monzon') and CDFGB flat, sometimes described as minor pentatonic (because of its flat seventh) (for example, as in the song 'Bakari Jan' or 'Sarafo'). However, these scales are not tempered, and intonation of particular pitches can vary in both vocal and instrumental performance, especially the second degree of the scale, which may be either flattened or sharpened as to sound between a major and a minor third, once again strongly reminiscent of the "blues third'. The ambiguous third in a pentatonic scale is a feature of some other musical traditions in Mali, including that of hunters' associations from the Wasulu region in the south of the country, ${ }^{31}$ whose music also is felt to sound close to the blues. No specific research has been conducted on the relationship between Wasulu hunters and Bamana jeli music, though it is well known that hunters' music predates and contributes to that of Mande jeliw (see Charry 2000a, 89).

The pentatonic scales of the Bamana repertoire are a significant factor in its limited circulation outside of the middle Niger valley. Musicians who belong to heptatonic (seven-note) musical cultures (Maninka, Khassonke, Mandinka, Wolof) seem to find it difficult to perform the pentatonic (five-note) music - and vice versa. This creates a fundamental musical divide between heptatonic and pentatonic-based music, 'which in effect means that the two live in different spheres' (Charry 2000a, 18), and is relevant to the story of which of the two is the more likely source of the roots of the blues. In my own experience, Maninka musicians often complain that Bamana singers cannot 'voice' Maninka music properly. Wassoulou artists such as Oumou Sangaré, who are firmly in the 'pentatonic camp', find it challenging to perform the heptatonic songs of the Maninka.

Preliminary investigation of the Bamana jeli repertoire reveals that it is relatively small, in terms of musically distinctive songs and accompaniments. (However most Bamana jeliw also include many pieces from the wider Mande repertoire, such as Sunjata.) Performances usually consist of a free-rhythm introduction on the ngoniba, which then goes into the ostinato accompaniment known as sen or riff. The vocals may consist of spoken recitation (tariku), punctuated by improvised singing (tèrèmèli), and choruses (dònkili) that are dedicated to specific characters or episodes in the epic.

While women may sing refrains or choruses (dònkili), recitation of the Bamana epics is invariably considered the work of male jeliw, using the mode of heightened speech known as tariku (see Durán 2007b). This was the mode of recitation that Bassekou Kouyaté used at the grave of Da Monzon, as described above. This mode of heightened speech is common among all the male griots of the middle Niger valley, including those of the Soninke and Fulbe ethnicities. There are no recordings on the international market of Bamana jeliw performing long recitations; mostly they are only available on local cassettes (see Newton 1999). Spoken recitation over the slow pentatonic accompaniment of the ngòiba bears a strong resemblance to the genre of blues known as 'talking blues'; for example, Robert Pete William's Prisoner's Talking Blues, recorded in 1957 while he was in the notorious Angola Prison on a murder charge. ${ }^{32}$ It is perhaps no coincidence that Robert Pete Williams was from Louisiana, the region to which many Bamana slaves were taken in the nineteenth century.

The Bamana repertoire consists mainly of a series of accompaniments and pre-composed songs that relate to specific rulers and warriors of the Segu Empire, in particular Bambugu Nce Diarra, son of Ngolo Diarra; Da Monzon Diarra, who ruled from 1808 to 1827 (as discussed above); and Bakari Jan Koné, a warrior by that name who was a contemporary of Da Monzon (see Conrad 1990). 
One of the difficulties of assessing the scope of the Bamana repertoire is that musicians may collapse the time span of these characters and sing about all of them in one song, moving from one tune and chorus to another without a break. This is the case, for example, of one of the best-known recordings of Bamana music, an LP dating from $c .1977$ by the Ensemble Instrumental National du Mali, entitled Dah Monzon ou l'épopée bambara, played frequently on Malian radio. ${ }^{33}$ It features a large ensemble with various Mande jeli instruments, a male speaker, a female chorus and a solo female singer, Hawa Dramé. Part 1 (side A) begins with a slow version of the 'Bambugu Nce' song, which, like many Bamana fasaw (praise songs), is a lament. Its chorus mourns the passing of several rulers, by saying that 'their (alcohol) drinking days are over'. ${ }^{34}$ Then at 5 " 21 it goes into the tune for 'Da Monzon', which remains the accompaniment until 15"40, when it changes into a faster, minor tune known as 'Segu tònjòn'. Part 2, on side B continues with the story of Bakari Jan. After the first minute of Da Monzon's tune, (including the chorus 'Ask Da' as described earlier on), the ensemble play Bakari Jan's tune ${ }^{35}$ (Figures 10 and 11).

Another praise song, also for Bambugu Nce, celebrates his building of a canal from the Niger to his village, Bambugu, east of Segu (see Conrad 1990, 133-141). ${ }^{36}$ It is one of the few Bamana tunes that is heptatonic rather than pentatonic. Nevertheless, in the popular imagination it has retained its core Bamana values, giving it a certain weightiness as a praise song for patrons.

One of the most often recorded of the Bamana jeli tunes is dedicated to the warrior Bakari Jan Koné. A kind of superhero with extraordinary strength, the song celebrates his victory against Bilisi, a monstrous and powerful sorcerer who caused terror in Segu with his disdain for human life:

When he [Bilisi] was on his way to the drinking house he would capture any child he happened to meet.

He would take him and give him to the brewmasters. He would sell him.

The next time he went out for a drink,

Whoever's virgin daughter he met,

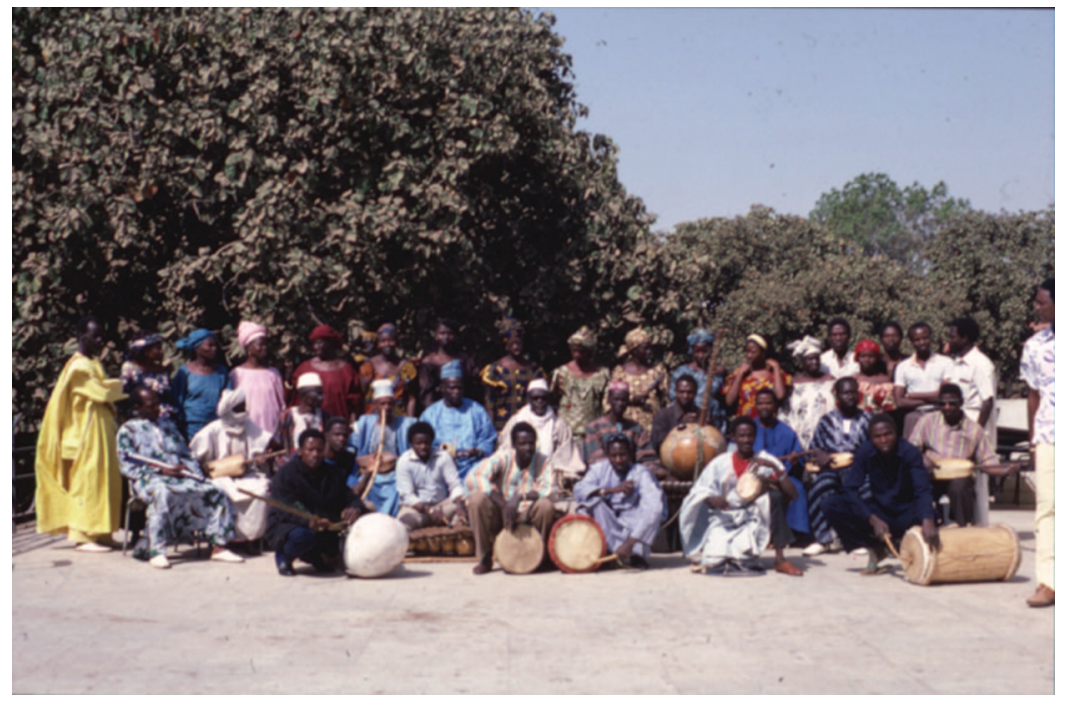

Figure 10. Ensemble Instrumental National du Mali, on the roof of their regular rehearsal space, the Carrefour des Jeunes, Bamako, 1986. Note the four ngòni players, from various ethnicities. 


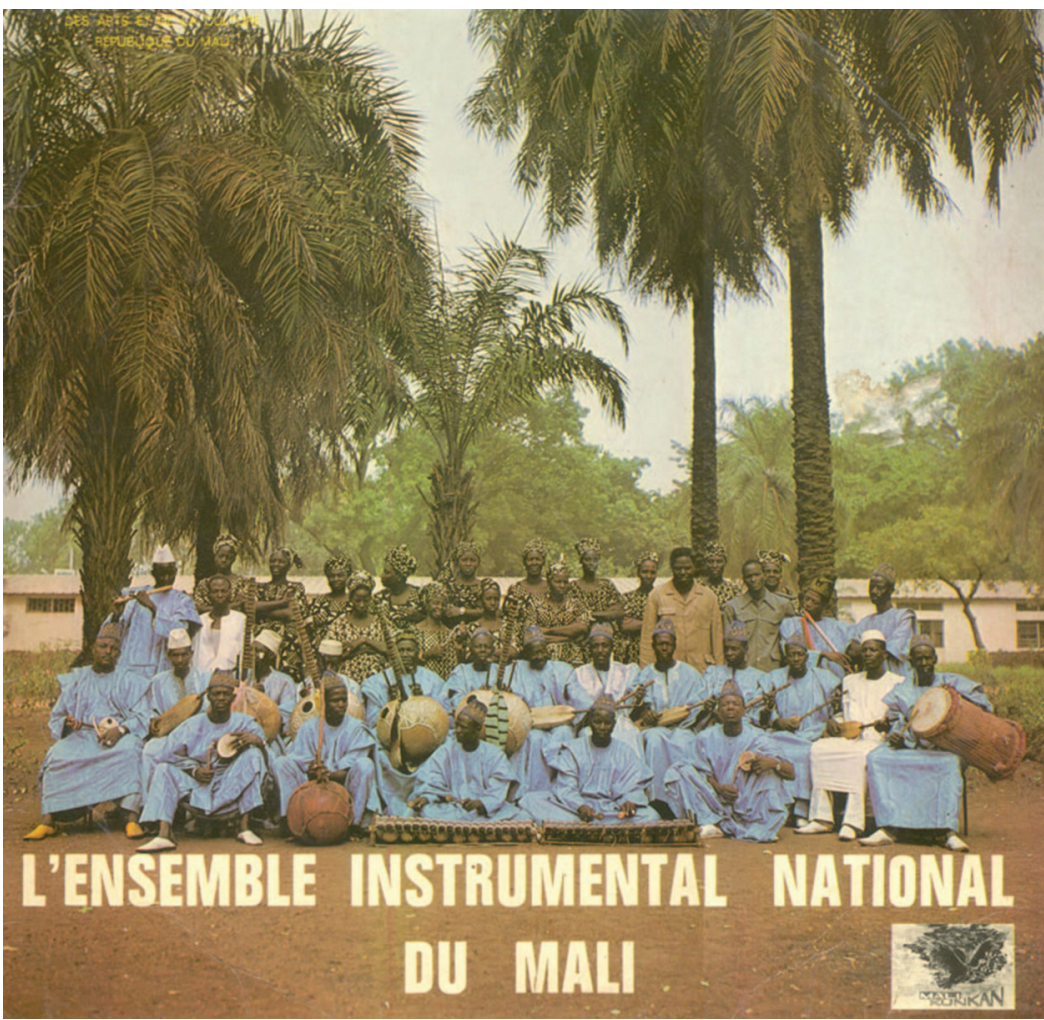

Figure 11. Cover of LP featuring the recording of Dah Monzon ou l'épopée Bambara, c. 1977.

He would capture and sell her.

(Tayiru Banbera in Conrad 1990, 271)

Bakari Jan is remembered not only for his prowess as a warrior but also for his love of the ngòniba - hence the opening chorus in his song, juru naani fò, jeliw be juru naani fò ('the four strings, the jeliw are playing the four strings'). The ngòni riff for this tune is in the minor pentatonic. ${ }^{37}$

Two pieces that occur frequently in the Bamana repertoire are 'Mbowdi' (variant spellings: M'Baoudi, Mbaoudi, Nbaoudi, M'baudi, Bawdi, Baudi) and 'Njaaro' (variant spellings: Djarou, Jaru, N'dyarou, Njaru). Both are almost certainly Fulbe in origin. This is not surprising, given that the Fulbe lived side by side with the Bamana for centuries, and finally destroyed the Segu Empire in 1861. Both terms Mbowdi and Njaaro appear to be Fulbe/Fulani. In Taylor's (1995) Fulani-English dictionary, bawde is translated as 'powers, capabilities', and bawdo as an 'able, capable, experienced person'. Njaru is defined as a 'feast, festivities', the kind of festivity that was held the night before the battle to rally the warriors. By contrast, in Bailleul's (1996) 'Bambara-French' dictionary, neither mbowdi nor njaaro are listed.

'Mbowdi' and 'Njaaro' share musical features with 'Poyi'. They are pentatonic, in slow tempo, and considered amongst the most 'sacred' and powerful in the Bamana repertoire. Frobenius cites 'the Baudi' as an epic tradition of the Fulbe (Frobenius 1921, 165ff). Amongst the Djelgobe Fulbe in the northeast of Burkina Faso, near the border with Mali, the bawdi is a repertoire of the descendants of captives (riimaybe), who are 'dispossessed of their cultural origins after having 
been captured during wars or raids, or purchased from neighbouring powers by the Fulbe. In a recording of their music made by the Musée de l'Homme, bawdi are defined as drums (sing. mbaggu), and bawdi laamu are drums of power, 'a repertoire formerly performed in times of war to galvanize the warriors on their departure' (Loncke 1997). Once again, we see the battlefield as the context for this music - played by captives.

There are many recordings of 'Mbowdi' and 'Njaaro', played by the Fulbe, Soninke, Bamana and even Sonrai musicians - thus they are veritable songs of the Niger valley. ${ }^{38}$ Ali Farka Touré recorded 'Mbowdi' on guitar together with an ngóni player, Ousmane Gadjaka. ${ }^{39}$

Sleeve notes to a field recording of 'Njaru' by Fulbe griots in Mopti, Mali, defines 'Njaru' as 'stimulation of the world of the Fulani'. The music is a rapid-fire spoken panegyric accompanied on the Fulbe four-string lute, the hoddu (Brandes and Malé 2008). The Soninke gambare player, Demba Fadiga, has recorded a track called 'Nbaoudi' with spoken recitation in Soninke, interspersed with vocals by a female singer in Bamanankan, praising a Fulani patron. ${ }^{40}$ Even if 'Mbowdi' and 'Njaro' are Fulbe in origin, they have been thoroughly absorbed into the Bamana tradition.

\section{Bamana jeli music in the public sphere}

Why is Bamana music not better known outside the region, either in scholarship or through recordings? One reason is that the epic tradition of Bamana Segu has never had the kind of wide exposure as that of the story of Sunjata Keita. There is no ritual space or time for its recitation, such as the re-roofing of Sunjata's sacred hut in Kangaba every seven years (Jansen 1997; Ganay 1995). Conrad found, while first working in 1976 with Tayiru Banbera (who was generally acknowledged as one of the most 'knowledgeable and skilled raconteurs of Mali') that even this celebrated jeli was performing on an infrequent basis (Conrad 1990, 4-5). The American scholar Robert Newton, as part of his investigation into the Bamana epics, attended an event in 1994 in 835 honour of the great Bamana warrior Bakari Jan Kone at Djoforongo, but was somewhat dismayed to find that the only music played was an old recording of the 'Bakari Jan' song, by Mali's Ensemble Instrumental National du Mali (Newton 1999).

As already stated, Mali's first government under President Modibo Keita favoured the Bamana style over others. During the height of Mali's dance band era, the Orchestre Régional de Ségou, later renamed Super Biton de Ségou, were the pioneering modernizers of the Bamana style and repertoire. They were the first orchestra to perform an arrangement of part of the Bamana epic, at the first Biennale of Arts and Culture for the Young in 1970 (Mazzoleni 2011, 81). The song, titled 'Da Monzon', is 12.14 minutes long - much longer than most recordings by local dance bands of the time. It includes the traditional accompaniment and chorus, $D a$ nyininka ('ask Da'), and a spoken recitation of excerpts of the story, over a full horn section and electric guitars. At c. 8.45 minutes into the recording, the tune changes to Segu tabali tè (Figures 12 and 13).

The balance between the slow pentatonic Bamana style versus those of the heptatonic and faster Maninka songs began, however, to tip in favour of the latter under the rule of Moussa Traoré, Mali's second president (1968-1991). One reason for this was the popularity of neighbouring Guinea's dance bands, who drew primarily on the heptatonic Maninka styles of upper Guinea, with arrangements and instrumentation borrowed from Cuban as well as Congolese music, with which they had many musical features in common. ${ }^{41}$ Cuban and Congolese music however did not mesh as well with the more harmonically static and slow, pentatonic Bamana repertoire.

As is well known, recordings of Cuban music circulated widely in West Africa after World War II. By contrast, there is little evidence of direct exposure to the blues in Guinea and Mali 


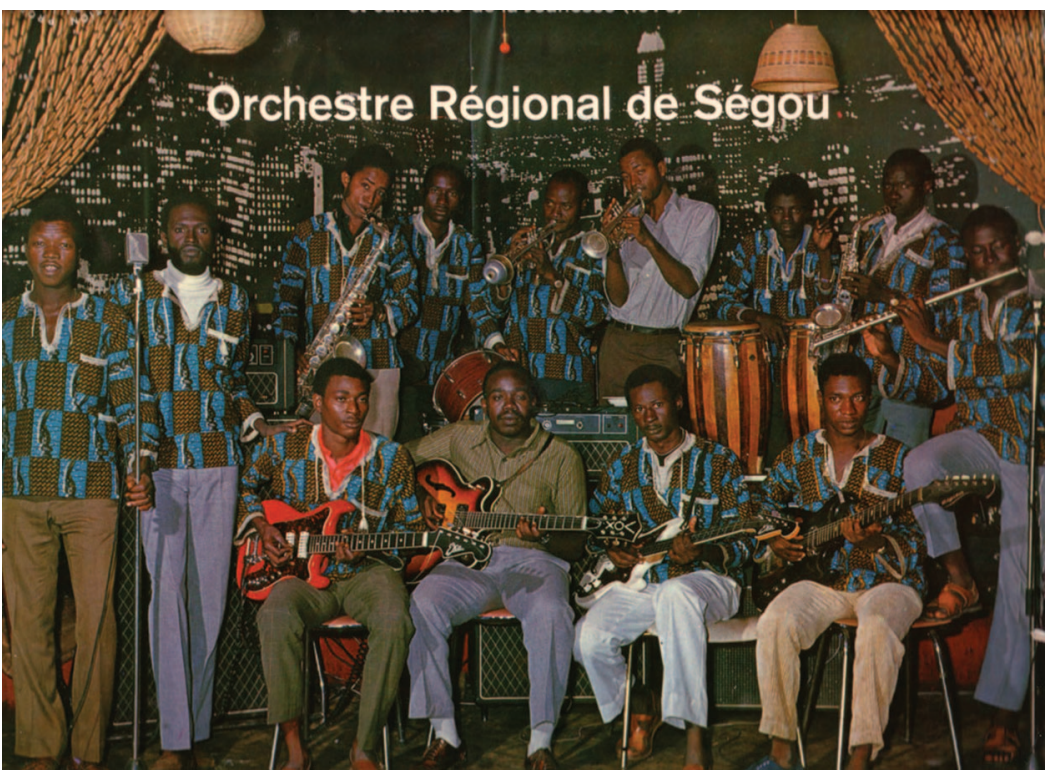

Figure 12. Cover of an LP issued in Mali in 1970 as part of the Anthology of Malian Music series (Barenreiter Musicaphon BM 30 L 2601), featuring the band that later renamed itself Super Biton de Segou.

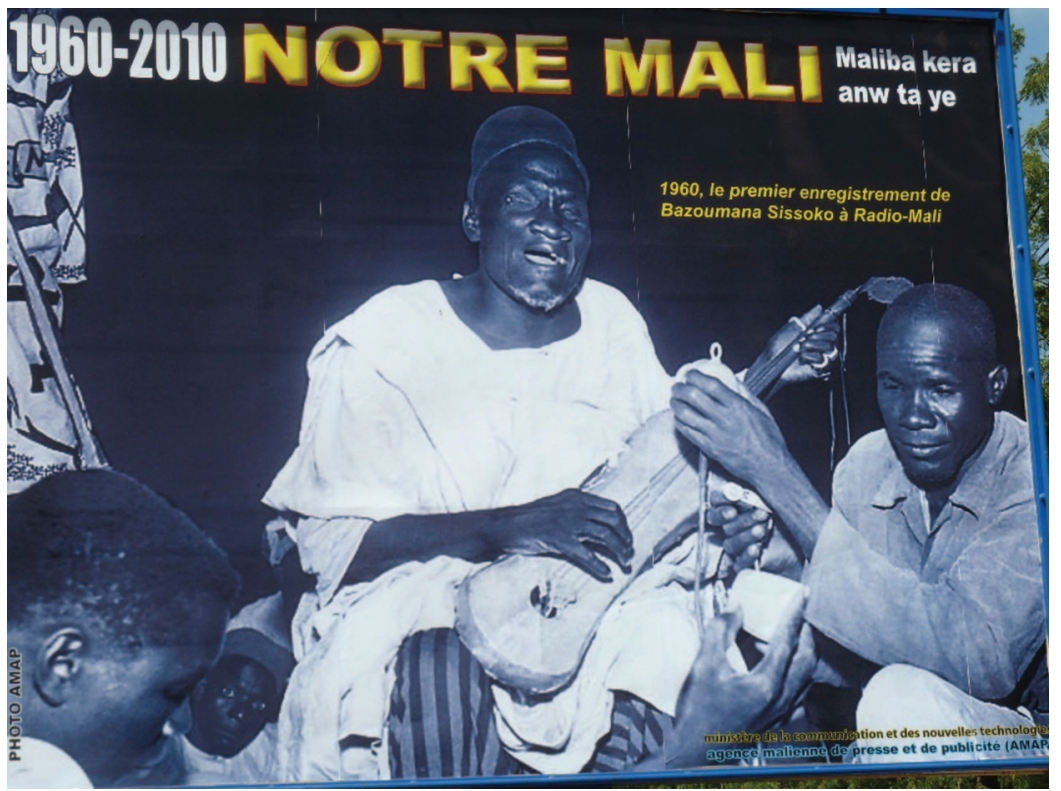

Figure 13. Cinquantenaire (50th anniversary of independence) photo of Banzoumana Sissoko, 'Le vieux lion', recording 'Mali', Bamako 2010.

AQ80 Source:.

during this period. It is more likely that knowledge of the blues was received via rock ' $n$ ' roll and jazz recordings. Louis Armstrong visited Mali in 1967, making an enormous impression on the director of the Orchestre Régional de Ségou, trumpeter Amadou Ba (Mazzoleni 2011, 79), but 
there is no evidence that any blues musicians visited the country. The word 'blues' is rarely referenced in the music of either Guinea or Mali until the $1990 \mathrm{~s} .{ }^{42}$

With the decline in popularity of Mali's dance bands from the 1980s onward, and the end of the Biennale festivals, Bamana music had a much lower profile than some other regional traditions. Only a few artists such as the singer Abdoulaye Diabaté, former lead vocalist with Kéné Star, continued to champion the pentatonic Bamana style, singing in the Segu dialect of Bamanan. In the absence of Bamana music on the scene in Bamako, some foreign scholars even concluded that all jeliya, the music of the Mande jeliw, is essentially heptatonic. $^{43}$

The 1990s saw the meteoric rise in Bamako of the popularity of the jelimuso (female jeli) and a style of music that developed around the wedding party circuit in Bamako, a style which continues to dominate in the twenty-first century. The Bamana ngòni has no place in the ensembles that accompany these singers. Instead it is the smaller and higher-pitched Maninka griot lutes (nkòni, kòni) that feature alongside electric guitars - not the lower-pitched Bamana ngòniba, whose sound is considered too 'masculine' (Figure 14).

Even the choice of skin for the sound table of the ngòniba is conceptually 'masculine'.

Until very recently, we only used the skin from the head of a cow for the ngòni, because the ngòni is like the head of the family, who is always a man. So only men can play it. It was not intended for women's ears ... We would talk about wars and battles, slaves and warriors; this was male conversation (cè baro).

The music of the Bamana ngòni has power. Because there are many Bamana powerful kings remembered by the ngòni. Because the Bamana kings had the power of the boliw [shrines]. Now, we live in the era of human rights and electricity. So the ngòni is changing. Now, we don't sing about wars, we sing about the problems of life today - health, money, marriage, children, schools, politics. And the cow skin can come from any part of the cow, we're in such a hurry to make new instruments and sell them. (Bassekou Kouyaté, personal communication 2007).

Bamana jeli music is considered by its practitioners to be cèfoli-music by men for men. ${ }^{44}$ In that respect, it runs counter to the musical trends in Mali described by some authors as the 'feminization' of Malian music, whereby women singers are the main stars, and where radio, television and wedding parties with music are their main platforms (Diawara 1996; Durán 2000; Schulz 2001). The Bamana sound is often described by Malians as 'heavy', 'sombre', 'powerful', and 'masculine', all of which would sit equally well with the blues.

Bassekou Kouyaté's acoustic band Ngoniba, created in 2006, has renewed awareness of Bamana jeli music among local audiences in Mali, and also taken it to international audiences for the first time. Ngoniba is a quartet of different-sized ngònis, including the ngòniba, and a larger, bass ngòni invented especially for the group - which includes percussion and the voice of Bassekou's wife, the singer Amy Sacko. Bassekou's idea of making an acoustic ensemble out of the same instruments has been influential among young musicians in Bamako, and the ngòni is currently enjoying something of a revival ${ }^{45}$ (Figure 15).

\section{The Bamana ngòniba}

Boat-shaped or round plucked lutes with skin sound tables and pole-like fretless necks are found with a variety of names across savannah West Africa. The playing techniques and styles of the Bamana ngòni reflect the porous boundaries between historically connected traditions of neighbouring ethnicities to the Bamana, such as the Fulbe and Soninke; professional hereditary musicians (griots) of the region have always made it their business to learn and appropriate each other's repertoires.

Charry's comprehensive review of these lutes classifies them into two main morphological types, differentiated by the shape of their bridges, by their geographical distribution, and by 


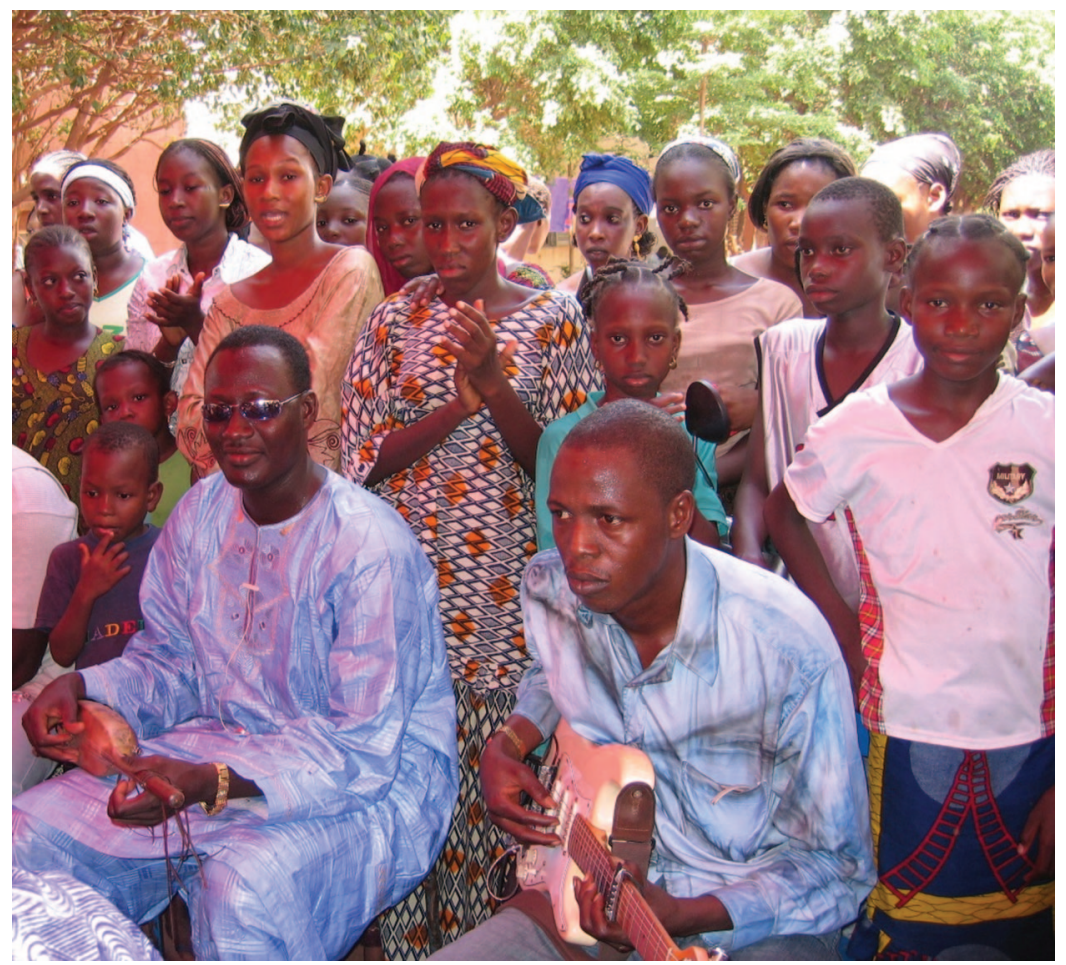

Figure 14. Ba Issa Koné (left) playing the small Maninka ngòni, and Modibo Djan Diabate on electric guitar, at a wedding party in Bamako, 2005.

Source:

which kind of musician, griot or non-griot, plays them. Which of the two - griot or non-griot and from which particular culture the ancestor of the banjo comes, is not known (Kubik 1999, 16). One issue here is the claim that griots were never enslaved, ${ }^{46}$ because they possessed valuable information for the survival and honour of lineages. Stories are common amongst jeliw of ancestors who were threatened with death, but always managed to talk their way out of it. Jeliw themselves were slave owners. If their patron was killed or overthrown, they would change allegiance to the new rulers, rather than be enslaved. Banzoumana Sissoko, the 'Old Lion', famously said in the early years of post-independence: 'in the rivalries between African parties, I refused to take a firm stand on one side or the other. I like the winner; therefore I like nobody before the end of the battle' (quoted in Keita 1995, 187).

Even if griots themselves were never enslaved, there is plenty of evidence to suggest that timbres and musical instruments from West African griot traditions were recreated by slave communities across the Atlantic. The banjo provides one example of this. Although we do not know which of the many West African lutes the banjo is descended from, the first account of the banjo in the New World dates as far back as 1678 (Conway 1995, 56), and it was a favourite instrument of slaves, described in one account as 'their beloved banjar' (Conway 1995, 58). There are many references to black banjo players in Louisiana in the early nineteenth century (Conway 1995, 59), which, as we have seen above, coincides with the period of intense slave trade from the Segu Empire, and to which many Bamana slaves were taken. The music of the slave banjo was certainly one element that contributed to the birth of the rural blues (Kubik 1999; Conway 1995).

AQ13 AQ14 AQ15 


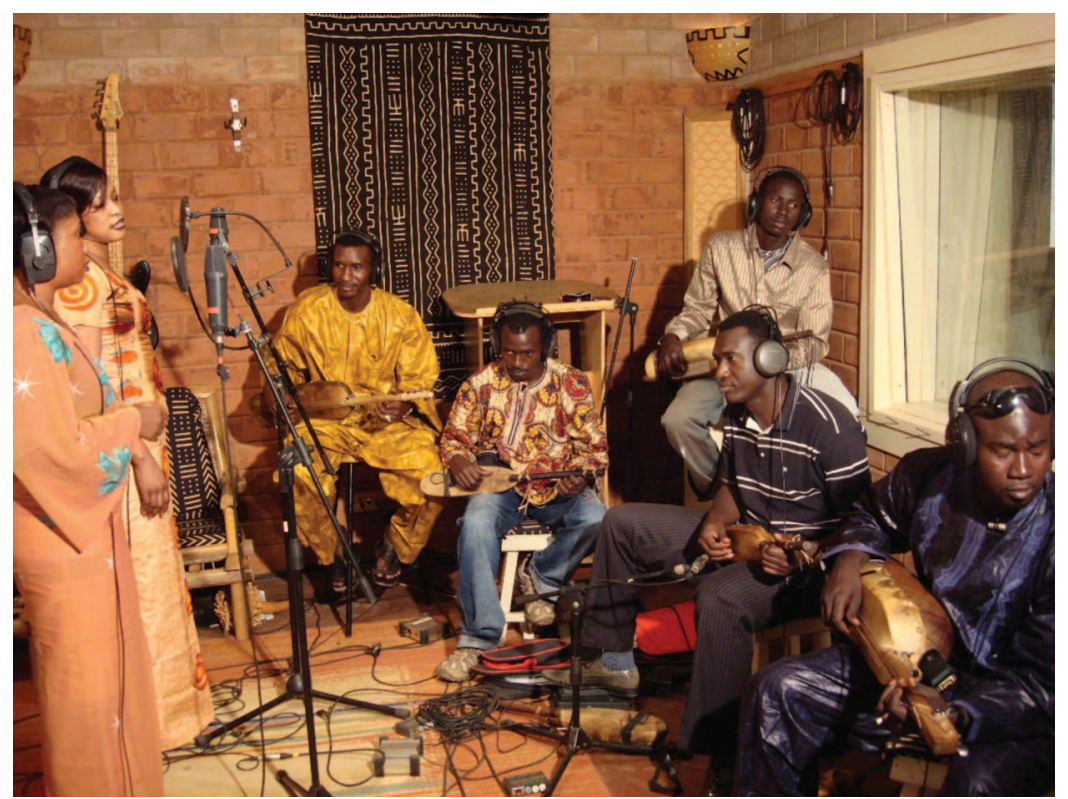

Figure 15. Ngoniba in the Bogolan studios, Bamako, while recording their 2009 album, I speak fula. Bassekou Kouyate is second from right and his wife, the singer Amy Sacko, is second from left.

The fretless neck of the West African griot lutes makes it possible to vary pitches, as opposed to the fixed pitches of the kora and the hunters' harp (other contenders for the origin of the blues). Bending, sliding, 'wavy' intonation, and ambiguous thirds, fifths and sevenths are intrinsic to the ngòiba and cannot be attributed to contact with the blues. They can be heard clearly on older recordings from the 1950s and 1960s featuring major Bamana artists of the time, who were most unlikely to have ever heard any recordings of the blues and who were known to be fiercely traditional in outlook.

The Bamana ngòni falls into the category of wooden-trough lute with a fan-shaped bridge, which Charry calls 'griot lutes' - 'probably the oldest melody instrument used by griots, dating back perhaps many centuries before it was first mentioned by Al-Umari and Ibn Battuta in the fourteenth century' (Charry 1996, 9). The Bamana ngòniba has four strings, of which only two are stopped against the neck, while a third string, the shortest (nearest to the head of the player), is plucked by the thumb as a kind of drone, plus a fourth string that is plucked open as melody. This non-sequential arrangement of pitches (sometimes termed a 're-entrant tuning') is also found on the banjo.

There are two main Bamana ngòniba tunings, called jè (meaning white) and erediné. The latter name is confusing, as it is phonetically close to both ardin and 'ordinaire', terms that are widely used for tunings on a variety of local lutes (see Charry 2000, 162-163, for lists of lute tunings with names and staff notation). 'Ordinaire' is probably a French-language corruption of ardin, which is the name of the Moorish harp played by female Moorish griots (tigiwit, iggawen). Charry cites Coolen's etymology for ardin as the Fulbe word ardo "to lead", or in another context, a certain kind of Fulbe warrior leader" (Charry $2000,164)$. Once again, we find the connection between warriors and the lute. There is also a kora tuning known as hardino, 'most probably borrowed from the koni' (Charry 2000, 164). 
The ngòiba tuning called erediné is exactly the same as that cited by Charry as Tutu Jara Ardin (Charry 2000, 163) (minus the fifth or highest pitch string, furthest away from the head of the player). 'Tutu Jara' is one of the best known pieces of the Bamana jeli repertoire, and its use as a name for a Wolof xalam tuning, combined with ardin, reinforces the view that the Bamana ngòni and its more northern variants, the Soninke gambare and the Moorish tidinit, have been important sources for styles and repertoires throughout the region. As Charry says, 'the relationship between these three uses of ardin - Moorish harp, a koni (and xalam) tuning, and a Mandinka kora tuning - is not clear, but it does indicate some process of diffusion at work among griots of neighbouring ethnic groups' (Charry 2000, 164).

The other tuning, jè (white) is, according to various ngòniba players, the original tuning for 1045 accompanying singers. Bassekou Kouyaté claims that his father Moustapha Kouyate (died $c$. 1984) only ever used this tuning. It is the same as the xalam tuning called Tutu Jara ordinaire, minus the fifth and highest string, cited in Charry (Charry 2000, 163). The use of Tutu Jara in the name of a xalam tuning shows the influence from the Mande tradition.

The principal way of sounding the ngòiba strings is with a downwards movement using only the thumb, index and middle fingers. The downwards strike allows the player to flick back with a rhythmic tap against the sound table. ${ }^{47}$ This added percussive element has been borrowed by kora players, who occasionally tap the wooden handle of the instrument with the knuckle of their first finger.

'Frailing', 'claw-hammering', (to use banjo terminology) and damping of the strings are old playing techniques used on all griot lutes of the middle Niger, as are bending, hammering and sliding notes on the neck. In the mid 1980s, Bassekou Kouyaté introduced a new way of plucking the strings, with an upwards stroke, using for the first time all three fingers, making it easier to produce fast solos to mirror those of the guitar but also thereby changing the acoustic, making it sound more like a kora (Bassekou Kouyaté, personal communication 2007). For this reason, audiences often confuse the sound of the ngoni with that of the kora.

According to Charry, the Bamana ngòiba is the largest of the griot lutes. Its wooden resonator has a slight concave or waist, as opposed to the canoe-shaped resonators of the smaller lutes in the Senegambia region and upper Guinea (Figure 16).

This larger type of lute is not exclusive to the Bamana, but is also played by griots of the Fulbe (who call it hoddu), and the Soninke (who call it gambare). It was almost certainly the instrument that was transported by slaves to Morocco and transformed into the gimbri, the lute of the Gnawa Sufi brotherhoods, whose oral traditions specifically trace their ancestry to the 'Bambara'. Charry suggests that the name gimbri is derived from the Soninke gambare (Charry 1996, 14), reflecting the important role of the Soninke as a point of diffusion of musical styles, instruments and linguistic terms in the region (Figure 17).

In the search for the origins of this instrument type, Charry refutes Farmer's theory that it came from ancient Egypt, and calls for further investigation into movements of 'Soninke and other Mande peoples north into Morocco ... Any link with ancient Egypt would most likely have reached the North African Gnawa gimbri via the south from where it originated. That link would most likely have been the Soninke gambare' (Charry 1996, 12-13). A full exploration of the musical connections with Soninke culture is beyond the scope of this article; however, the regional importance of the Soninke gambare as the ancestral lute takes on extra significance in our discussion of the song 'Poyi'.

The ngoniba was the only melody instrument that Segu jeliw played during the time of the Segu Empire. There is no evidence that either the kora or the Maninka balafon ever made their way to the courts of the middle Niger valley. So emblematic of the Bamana tradition is the lute, that bamanangoni is used as a generic term to describe Bamana music (Brandes and Malé 1998). 


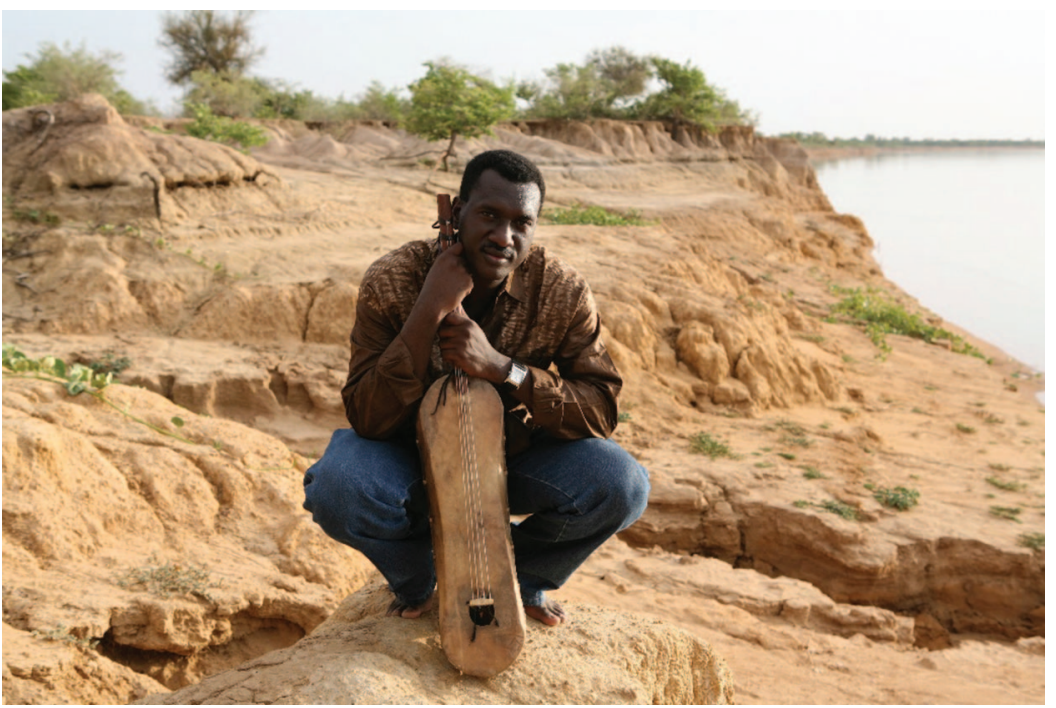

Figure 16. Bassekou Kouyaté at the Niger near his village, Garana, holding the Bamana ngòniba. Note the slight waist on the resonator, the bridge attached to the end of the neck, and four strings.

Source: Thomas Dorn, 2007, by permission.

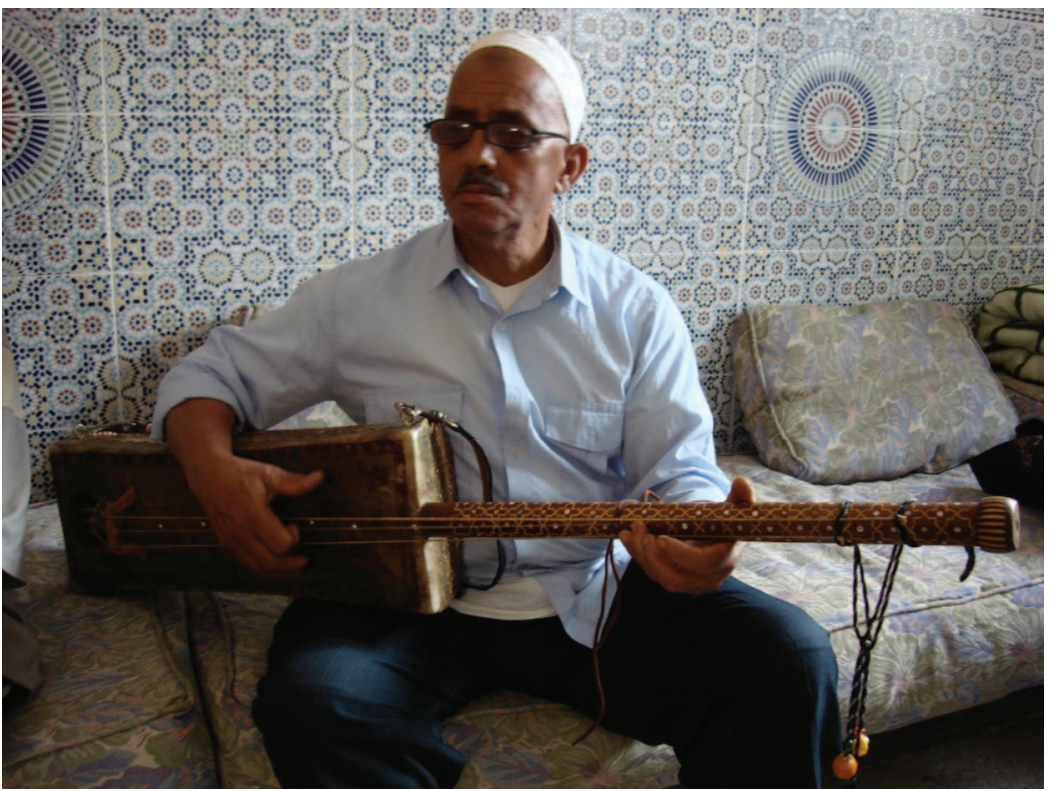

Figure 17. The gimbri, played by a member of the Gnawa brotherhood in Essaouira, Morocco, 2009. Source:

Evidence for the existence of the ngòni as the favoured instrument of Segu Bamana's rulers comes from oral tradition, as in the following extract from an epic recitation by Kabiné Sissoko:

Da Monzon reigned in Segu, 
where the tonjons [slave army] had built

a palace with seven vestibules

Thirty-five guitars [ngònis] flattered the ears of the king

$\left(\right.$ Kesteloot 1993, 34) ${ }^{48}$

This may be hyperbole; it is usual for jeliw to boast of their importance in pre-colonial times. However, a twentieth-century descendant of the Diarra dynasty, Gaoussou Diarra, attested that his ancestor Monzon Diarra (who ruled Segu from 1787 to 1808) had in his entourage 740 jeliw who were 'fearless warriors, a law unto themselves ... They took the best horses, chose the best women, and wore a silver bracelet on their left arm and a gold earring on their right ear' (Sauvageot, quoted in Kesteloot and Dumestre 1975, 10-11, fn. My translation). Tayiru Banbera's epic recitation places the jeli Tinyetigiba Danté at the centre of the intrigues that unfold at the court of Segu during the rule of Da Monzon Diarra. It is Danté who advises Da Monzon at all times on all matters of both war and love.

Despite the descriptions of large ensembles of lutes at the court of Segu, the only time such an orchestra has existed in living memory is when Bassekou Kouyate brought 50 ngoni players to perform at the presidential palace in September 2010, as part of the 50th anniversary of independence celebrations. Otherwise, the Bamana ngòniba is usually played on its own or with one other ngòni, accompanying recitation ${ }^{49}$ (see for example, Frobenius 1921, 108-110; Kesteloot and Dumestre 1975; and also recordings of Fotigui Diabaté, in Brandes and Malé 1998).

\section{'Falling a little differently'50 - 'Poyi' and the blues}

We now return to the piece called 'Poyi', with which this investigation began, and its possible links with the blues. As we have seen in the description by the Kouyaté brothers in Garana, 'Poyi' is a tune played to accompany recitations of praise for bravery - as are many other pieces in the Mande jeli repertoire. But there is a special ethos to 'Poyi'.

Poyi is a sacred [ritual] piece. It recalls three things: new life, fresh blood, fresh excrement. It's a tune that you make an oath on. If you swear on Poyi that you will do something, you're obliged to fulfil your promise, or otherwise, you'd better hide behind your mother! It's like Janjun, but more powerful. Janjun is for the griots, but Poyi is for the true nobility. If a noble swears on Poyi and doesn't keep his word, he'll be at the bottom of the ladder of his entire race. It's like that. (Bassekou Kouyaté, personal communication, London 2013) (1 $^{51}$

How can such oral testimony be corroborated? The picture is complicated by the paucity of recordings with the title 'Poyi' (or similar spellings). A bit of detective work is therefore required. By piecing together evidence from ethnolinguistics, a few local recordings, transcriptions of epic recitations and references in obscure literary texts, a convincing case emerges for this tune as being different from all other Bamana tunes. In essence, it is an instrumental accompaniment over which oaths would be sworn, or war captives would take their decision to live as slaves or die as warriors.

One of the few named recordings of the piece, called 'Poi', is found on a cassette featuring Banzoumana Sissoko, the 'Old Lion', who (as already stated) was one of the most influential and respected musicians of the post-independence era. The exact provenance or date of this recording is not known, but it most probably was recorded for Radio Mali in the 1960s. Interestingly, the other two pieces on the cassette are both major 'ritual' pieces in the Mande jeli repertoire: 'Sunjata' and 'Janjon'. On the recording Banzoumana accompanies himself on the ngoniba; the traditional iron rattle placed on the end of the neck can be heard clearly. The piece begins with a sung recitation, but quickly turns into an instrumental performance - probably the only 
instrumental that the Old Lion ever recorded. Bassekou states that there are three or four regional variants of 'Poyi', all of which are 'minor' pentatonic and in slow 6/8, and that Banzoumana - Bassekou's grandfather - had his own individual way of playing it. ${ }^{52}$ Another instrumental recording, cited as 'Poyi, le blues du griot' is played by the musician Amadou Diarra on the ngòniba. ${ }^{53}$ There are surely many others, for which further research is required (Figure 18).

The polysemous vocable poyi (with its variant spellings: poui, pui, puyi, poi) may carry as much weight as the music itself. Poyi is listed in the main Bamana-French dictionary as a 'poem or epic - griot vocabulary', and also as a verb, 'to appear suddenly' (Bailleul 1996). Its use is widespread in the countryside of southern and central Mali, where it denotes strength and exceptional bravery. Some informants have told me that it is onomatopoeic, conveying the noise of an arrow or sword slicing the air, or a scythe cutting through grasses. In the Wasulu region, which has produced some of Mali's most popular music over the past two decades, Poyi is a term for praising a strong farmer or hunter. 'Poyi' or 'Poyi sensen' is the name of the first song that one learns to play on the kamalengòni. The wassoulou musician Kokanko Sata explains that 'Poyi sensen was the first song I learnt - it means a strong worker, a brave young man - Poyi sensen means to walk slowly, in front, steadily, without fear' (personal communication with the author, 2005).

In her study of wassoulou music, Heather Maxwell considers that

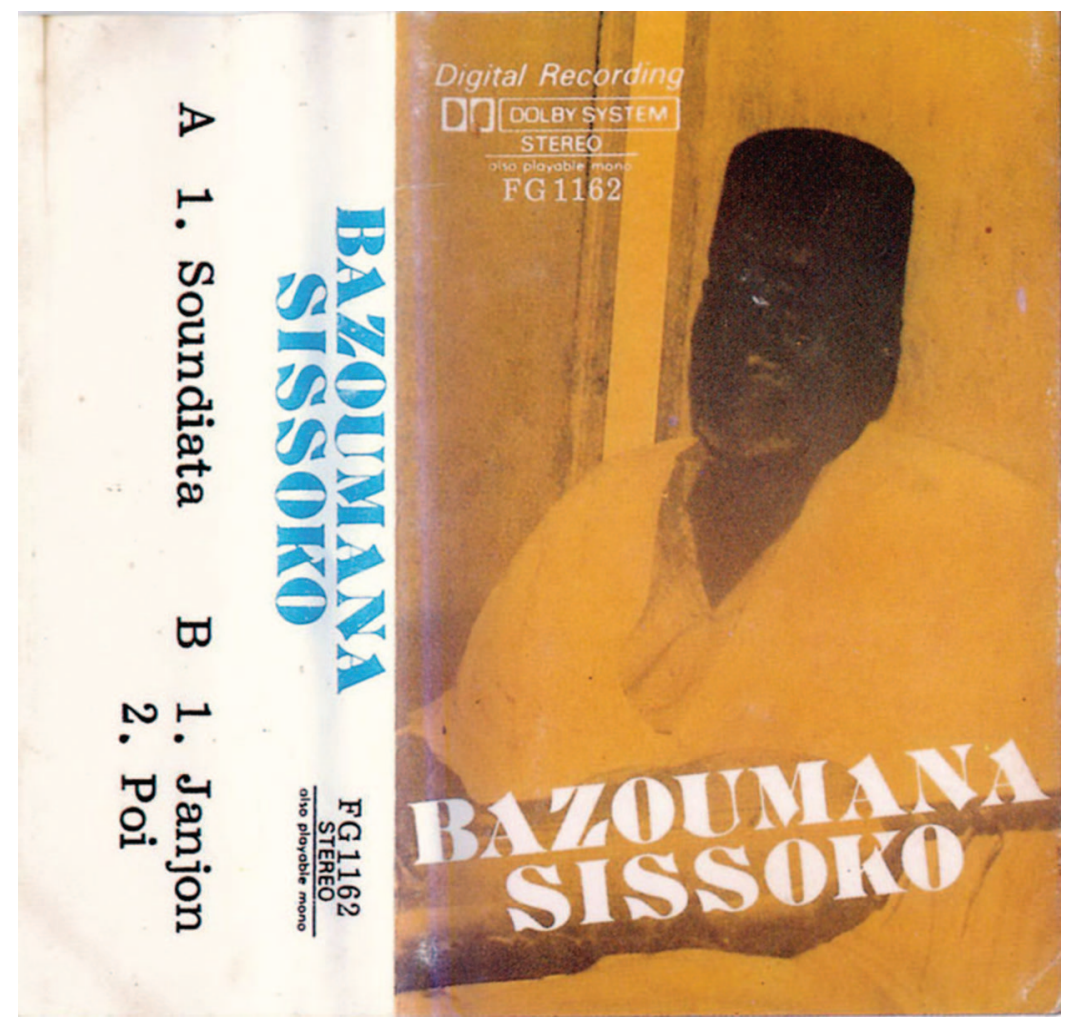

Figure 18. A local cassette copy of a Radio Mali recording by Banzoumana Sissoko [using the spelling Bazoumana]. 
Poyi is a borrowed word from the specialized jeli vocabulary but its meaning is polyvalent. Poyi, also meaning foli in Bamanankan, means a poem, an epic, to greet, salute, thanks, and speak. It is a heavily weighted word ... (Maxwell 2002, 181-182)

'Poyi' was also the name of a song from the upper Niger in Guinea, accompanied on the dan (a now almost extinct calabash-resonated pluriarc that was one of the precursors of the Wasulu youth harp). Meaning 'going', 'Poyi' was 'dedicated to war veterans and young men who achieved something special for the public good' (Camara 2002, 63).

Coumba Sidibé, one of the pioneers of wassoulou, ${ }^{54}$ recorded a popular track entitled Pouikanpoui. It opens with a man exclaiming 'Poyi! Pouikanpoui!', the sound of which is echoed with ringing harmonics on the kamalengoni (youth harp). In fact, it is not uncommon to hear exclamations of 'poyi' at the beginnings of Bamana songs, articulated in a plosive manner, as if conjuring the sound of a bullet whistling through the air. (The late Lobi Traoré, Bamana guitarist and singer from Segou, whose music has been called the 'Bambara blues', ${ }^{55}$ often opened his performances at nightclubs in Bamako by shouting 'poyi!'.) I have also heard that the term poyi was shouted during wrestling matches in Mali during the first decades of independence, to encourage champion wrestlers.

Such exclamations are also found in the line-by-line transcription of a little-known episode from the Bamana Segu epic, concerning the siege of Jonkoloni (French spelling Dionkoloni), a well-guarded fortress town some $200 \mathrm{~km}$ northwest of Segou, during the reign of Da Monzon (1808-1827). The story goes that Da Monzon wished to annex the town to his empire, but, according to the jeliw, Jonkoloni had recourse to great mystic power, capable of rebuffing all the attempts of Da Monzon Diarra's dreaded tònjòn army. The story revolves around a hero by the name of Silamakan, and there are many overlaps with a Fulbe epic, Silamaka et Poullori (see Belcher 1999).

Kabiné Sissoko, a Bamana jeli originally from Segou, performed a recitation of 'Dionkoloni' in Bamako in 1968 for the French scholars, Kesteloot and Dumestre, accompanying himself on the ngoniba. Sissoko had been the apprentice of Banzoumana Sissoko, the 'Old Lion', for six years (Kesteloot and Dumestre 1975, 22), and he may well have learnt the tune from his master, who was the first to record 'Jonkoloni'. ${ }^{56}$

In Kesteloot and Dumestre's bilingual (Bamana-French) transcription of Kabiné Sissoko's performance, the term 'Poyi!' occurs from time to time at beginnings and endings of sections - a kind of sonic and metaphorical representation of power:

$\mathrm{Da}$ [Monzon] declared that he would never give up the fight to Jonkoloni; Jonkoloni said she [the town] would never fear Da Monzon. Poyi! (Kesteloot and Dumestre 1975, 51);

Mariheri of Jonkoloni claims that he can drink the poyi juice ... ( Kesteloot and Dumestre 1975, 43); Poyi! iron slurry, cold water that puts out the fire, the big drum that blocks the path, the madman who settles in the ruin, the stranger with a dirty head at the end of the field (Kesteloot and Dumestre 1975, 113);

Jonkoloni is a wasps' nest, a scorpions' nest, it's a city of valiant knights, this is the truth! And now, poyi! (Kesteloot and Dumestre 1975, 115).

(translations mine)

There is, however, one view that Poyi was a Bamana genre of recent origin, connected to the rise of radio broadcasting in Mali. The Malian anthropologist and politician Pascale Baba Couloubaly stated

the 'poi' tends towards fantasy and boisterousness, as can be seen in the performances of Jeli Baba Sisoko and in those of the 'poikanpoi' group. Jeli Baba Sissoko is a well-known griot and radio announcer whose Tuesday evening broadcasts have attracted a substantial audience both in Mali and in the Malian diaspora. The Tuesday evening 'poi' is a new style of narrative that has borrowed 
from all the traditional genres, while establishing a renewed focus on eroticism, luxury, wealth, and the miraculous. In doing so, Jeli Baba loosely translates tales from the thousand and one nights into the Bamana language and adopts the technique of Segou, thus redrawing, according to his own imagination, the countenance of a brave and warlike feudal Bamana society that has been morally undermined by women and money. (Couloubaly 1993, 59)

Couloubaly's description may focus on a new interpretation of 'Poyi', but it undoubtedly has resonances with the meanings that have already been explored in this article. It also mirrors an important but overlooked literary source on middle Niger epics - a little-known publication in German by Leo Frobenius, who travelled around Africa in the early twentieth century collecting oral traditions.

Volume six of Frobenius' (1921) 12-volume publication describes a series of heroic songs entitled 'Pui' (clearly a variant of poyi) collected amongst a Soninke community in Benin. Belcher, a scholar of African oral literature, questions whether these texts are genuinely of Soninke origin, 'for in fact the discernable language is more often than not Bamana, and the cultural horizon involved belongs not to single group but to a sort of generic heroic world that in modern and reliable transcriptions is best represented among the Fula' (Belcher 1999, 87). Conrad, too, believed that

many of Frobenius' conclusions are highly questionable ... and the possibility of the existence of the dausi and of the related genre of shorter material called pui as perceived by him, should be studied further before being accepted as having been part of West African tradition. (Conrad and Fisher 1983: fn. 156).

1280 Nevertheless Frobenius' description seems to confirm the evidence presented here on Poyi and suggests that Poyi was once a much more widespread performance genre than it is now. It is unlikely that knowledge of this rather obscure and old text in German, never republished and only available as a rare book in some libraries, would have fed back into the tradition.

Frobenius defines Pui as a collection of songs recounting the stories of 12 heroes of the region known as Kala in the northeast of Segou province; he states that every griot (he uses the term dialli [jeli], though mostly he does not cite indigenous names) knows at least one of these songs, though not all of them, nor are they performed as a unity or continuous story, unlike another genre that he cites, the Dausi. Frobenius explains that it was difficult to compile a complete document of the Pui, partly because 'titles differ'. Thus, Pui was a genre, not a specific piece (Frobenius 1921, 93). He also provides detailed and accurate line drawings (Frobenius 1921, 41) of what he describes as the 'bard's lute from Segu' which elsewhere he calls 'djuma koni' (Frobenius 1921, 44), but in the stories just calls 'guitar'.

The Pui stories Frobenius relates are infused with the kinds of Bamana values mentioned earlier in this article. They extol the virtues of bravery and honour, of keeping one's word. The metaphorical language is so idiomatic to that of the jeliw, that it is difficult to imagine that Frobenius could have made it up, and it contains some interesting references to the Pui itself.

At least one of the stories concerns a 'hero' from Kala, Sirrani Korro Samba, and a jeli, Signana Samba. One day, while Sirrani's wife is travelling, she is surrounded by 60 'heroes' from Segu, on the lookout for booty. ${ }^{57}$

She said: 'What kinds of robbers and vagabonds are you that even a respectable woman draws your attention? Aren't you ashamed to be standing around in the sun with your thievish thoughts, so that I can see each one?' Amazed, one of the sixty heroes said: 'Woman, what gives you the courage to speak thus to the sixty foremost heroes of Segu?' Sirrani Korro Samba's wife said: 'Oh, what great heroes you are, daring to talk so boldly to a woman. Just wait till my husband comes: he'll teach you to fart from fear... and there will soon be an end to your splendid courage in front of a woman.' Signana Samba, the jeli, struck on his guitar and said, 'if the courage of the husband of this woman does not belong in the Pui, then at least one should sing about the quick-witted responses of this woman. Woman, who is your husband?' 
Sirrani Korro Samba's wife answered: 'Who my husband is? Do you really want to know? Then you should hurry to look for mouse holes in the fields and birds' nests in the trees and hide there with your ponies. It's from there that you can best get to know my husband: but take care not to be trampled underfoot by his horse.' Massassi Diadierri said: 'Woman, you absolutely must accompany us to Segu, so that the king can learn something out of the ordinary. Has anyone ever heard such a bird sing? Onwards to Segu.'

The wife warns the 60 heroes that her husband Sirrani is drunk, and therefore especially dangerous. When Sirrani turns up, he takes three of the heroes prisoner, and the jeli taps on his lute and sings:

'You heroes of Segu, consider that you are sixty men who have been poisoned by a woman's mouth, and must now be slaughtered as sick people. Just think, that you are heroes, you sixty men from Segu.'

Then the jeli rode up to the woman and said: 'If this matter is ever to be sung in the Pui as it deserves to be, then we must get a jeli to do so, for these men running away are certainly not going to tell the story. But if the jeli reports this matter in the Pui, at that point he will be far away from the brave woman he has got to know that he wishes to sing about, too far for her to be able to make him a gift.' Thereupon the wife of Sirrani Korro Samba took off one of her heavy gold earrings and gave it to the jeli.

The story continues with the jeli creating on the spot a song that he calls 'One-sixty', with which he taunts the heroes of Segu by insinuating that the 60 of them had been defeated by the one hero from Kala. The jeli refers to 'the Pui' several times as if it were a medium through which brave deeds would be recounted, almost like a column in a newspaper. For instance, when the 60 heroes have returned to Segu - or rather, those who have survived and not been taken captives by Sirrani - the ruler demands that the jeli explain the meaning of 'One-sixty'.

The heroes all gathered in the evening. The jeli had hung his sixty-one gold rings on his guitar. The king asked: 'What is in Pui?' Samba said: 'One-sixty.' They all looked at him. Signana Samba asked Massassi Diadierri: 'How does one keep one's word, half or whole?' Massassi Diadierri said: 'One keeps one's word whole', and the jeli said 'One-sixty' ...

(Frobenius 1921, 106-110)

Frobenius' descriptions of the Pui are consistent with 'Poyi' as performed and later described to me by Bassekou Kouyaté and his family in Garana, on that day in 2006. They are also consistent with the Poyi songs in the Wasulu region, and the exclamations of Poyi! during Kabiné Sissoko's recitation of 'Dionkoloni', and by Bamana musicians in general. The difficulty of finding many named recordings of 'Poyi' could well reflect the fact that it is more of a generic concept than a specific tune, connected with a vanished cult of bravery on the battlefield, and, as such, is fading from memory amongst the younger generation of singers. It is also sometimes performed with the title of 'Mbawdi', a tune with which it shares various musical features.

In a sense, the most important thing about 'Poyi' is not so much what it might have sounded like during the era of Bamana Segu, or whether indeed, as several musicians have expressed, it can be seen as 'the original Bamana blues'. If, via the memories of captives, 'Poyi' and other Bamana tunes ever did reach the New World, they would in any case have most certainly been recreated in a 'thoroughly Atlantic way'.

Perhaps more to the point is that 'Poyi' is a window on the role of Bamana jeli music as part of the little researched and complex musical traditions of Mali's middle Niger valley, and their relationship with the blues.

\section{Conclusion}

Mali is frequently cited as one of the sources of the blues, yet the discussion is not nuanced, since there is almost no research available on the music of the middle Niger valley, and, until very recently, not many recordings either. Bamana jeli music is one of these traditions. Its musical 
resonances with the blues and with the banjo have had recent exposure on the international stage through the work of the ngòni player Bassekou Kouyaté. This article has attempted to document the historical reasons for these similarities, taking the little-known piece 'Poyi' as its starting point, suggesting that the context in which it was played, before and after battles, to warriors and war captives, and its ritual or 'sacred' ethos, provide an important missing piece in the quest for the roots of the blues.

The article provides the first detailed account of Bamana jeli music, with its emblematic instrument the ngoniba, its origins in the Bamana Segu Empire, its slow, bluesy tempo, pentatonic scales, male ethos, and lyrics that glorify fighting and bloodshed.

Although Bamana music is one of several middle Niger valley musical cultures that share traits with the rural blues of the Deep South, it may have been the principal conduit for the transatlantic flows of these traits, in view of Segu's culture of warfare during the eighteenth and nineteenth centuries, which generated thousands of slaves. They may have had a broader cultural impact than their small numbers would imply, perhaps even recreating the sonic memory of the last piece of music they might have heard before being sent westwards.

In the words of Kabiné Sissoko: 'and now, Poyi!'

\section{Notes}

1. Throughout this article I use two spellings for the region of Segou and its capital town. Segou is the French spelling that is widely used on maps and in literature, as French is Mali's official language, while Segu is the official DNAFLA spelling (Direction Nationale de l'Alphabetisation Fonctionnelle et de la Linguistique Appliquée). I use these different spellings to distinguish between references to pre-colonial Segu (cf. Conrad 1990) versus present-day Segou (the town and region).

2. In keeping with most English-language Mande scholarship, I have chosen to use the term Bamana rather than 'Bambara', the former being an endonym (that is, the term from the Bamana language itself), while the latter is mainly used in French-language literature and conversation (and also by some other ethnicities to refer to the Bamana). See Vydrine $(1999,71)$ for detailed discussion of the term Bamana. In general, I have used DNAFLA spelling for Bamana terms and song titles, except for surnames which are written with French orthography.

3. At this stage, in 2006, Bassekou had yet to record his first solo album, Segu blue (one of the first international recordings showcasing the Bamana ngòni).

4. The story of Dò Kamissa the buffalo woman is one of the best-known episodes of the Sunjata epic, and there are dozens of versions of it. See Conrad (2004, 30-51) for a line-by-line transcription of one

1380 5. For a full account of this empire as told by a Bamana jeli, see Conrad (1990).

6. More discussion of this is found later on in the article. The main study to date of Mande music (Charry 2000a), for example, does not include Bamana jeli music.

7. The blues scholar Paul Oliver points to the "blue notes" created by ... slide and sideways pressure on the string" as an intrinsic feature of the blues (Oliver 1982, 187).

8. This project eventually turned into Segu blue, the first of two albums that I produced by Bassekou Kouyaté and his group Ngoniba (Durán 2007a).

9. A version of 'Poyi' by Bassekou Kouyaté can be heard on track 14 of the album Segu blue. Another version by Bassekou can be seen in a live performance at the Royal Albert Hall in 2008 at http:// www.youtube.com/watch? $v=$ KA0ErTCqUPo. (Accessed 30 March 2013). Other recorded versions of 'Poyi' by other Malian artists are cited later on in this article.

10. Charry states that 'all the pieces played by jelis are named and have some kind of story behind them ... [they] are usually dedicated to a single person, such as a great leader, warrior, or patron' (Charry 2000a, 145).

11. See Charry, Camara, and Jensen (2002: 305) for discussion of the concept of shame as 'a crucial organizing factor in Mande society'.

12. I have been working with musicians in Mali since 1986, primarily as researcher but also as music producer and broadcaster. I have known Bassekou Kouyaté and his family since the early 1990s, but it was only in 2006 that I began researching Bamana music, following the encounter described above, which culminated in two albums by Bassekou Kouyaté featuring the ngòni (see Durán 2007a and 2009). In 
addition, from 2009 to 2012, I spent long periods in Mali working on a project to document children learning music in griot families, in Garana amongst other locations, funded by an AHRC Beyond Text major grant, 'Growing into Music' (2009-2012). Research in Segou during that project has contributed significantly to the present article (see https://www.growingintomusic.co.uk).

13. (Radio interview with Jay Rutledge, for Bayern 2, Bayerischer Rundfunk, Bavaria.) Ndoondo is one of the Fulbe genres of professional music; see for example Loncke (1997); it is also mentioned in the recitation of the 'Siege of Jonkoloni' (Kesteloot and Dumestre 1975, 85). 'Seygalare' is the title of one of Ali Farka's early recordings, on the album Radio Mali, WCD 044.

14. http://www.afropop.org/multi/interview/ID/112/Gerhard+Kubik-2007 (Accessed June 24, 2012).

15. While Kubik is right that Touré's success paved the way for others in Mali to be labelled as blues artists (Kubik 1990, 196), he is misinformed about aspects of Touré's life; for example, he did not spend long periods of time in Europe, or even in Bamako; in fact, he was well known to all those who knew him as someone who was openly antipathetic to life in Europe, and who chose to spend as much of his time as possible farming in Niafunke.

16. See for example the following websites, suggesting connections between the Senegambian Jola akonting with the banjo. The name akonting is borrowed from the Mandinka kontingo (a variant of ngòni): http://www.myspace.com/akonting; http://www.myspace.com/uncleshlomo; http://www.myspace.com/ banjoroots/blog.

17. This is quoted from a line about drinking alcohol, recited by Tayiru Banbera, and cited later on in this section.

18. The lack of performance contexts for Bamana epics is discussed later on.

19. An example of this is the song 'Mbowdi' on the album Segu Blue (Durán 2007a). 'Mbowdi', its place in the Bamana repertoire and its Fulbe origins are discussed later on in this article.

20. An example of this is the how the jelimuso (female jeli) Bako Dagnon got her name. Her paternal grandfather, Bouloukoumba Dagnon, took her grandmother, Bako Diarra, as 'booty' in the late 1800s, when passing through Segu, during the wars between the French army and Almami Samory Touré. Bako Dagnon (personal communication 2010).

21. See Conrad (1990, 1-4) for a concise description of the Bamana of Segu, their language, social structure and religious beliefs, and 13-29 for references to the many other published variants.

22. Al-Hajj Shaykh Umar Tall founded the Umarian state, which ruled until 1890 when Segou fell to the French army under General Achinard.

23. Tayiru Banbera however recites that this was not the 'real fasa for Da', citing instead a chorus 'rooster of the canoe-bow, take us forward with you. One chief along cannot be a whole army' (Banbera in Conrad 1990, 142). 'Ask Da for me' (Nyininka, Da nyininka) has been recorded in many popular variants by many artists and groups, including the Ensemble Instrumental National, the Super Biton, Banzoumana Sissoko, Koni Koumaré, and most recently Bassekou Kouyaté and Ngoniba. For further discussion of this song see Conrad (1990, 62).

24. The belief in jinns as the source of some kind of divine musical inspiration is also prevalent in Mande thought (Charry 2000a, 119). See Kubik $(1999,64)$ for discussion of the 'demonic' reputation of blues musicians and their use of 'evil magic'.

25. This speech, in French, was recorded as part of a radio documentary entitled 'Bambara Blues', recorded in and around Segou, broadcast on BBC Radio 3 on 24 March 2007, http://www.bbc.co.uk/programmes/ p005xlv6 (Accessed 1 July 2012).

26. I am grateful to Professor Owen Wright of SOAS for his translations from the original German.

27. The first kora players to tour the USA, in the early 1970s, were Alhaji Bai Konte and Jali Nyama Suso, both from the Gambia. Jali Nyama was the main informant in the pioneering research on Mandinka kora by Knight $(1972,1973)$.

28. See Durán (1981a and 1981b), Charry $(2000,154)$, Coolen $(1982,80-81)$ for further discussion of this tune in the Mandinka kora and Wolof xalam repertoire.

29. See Bird (1999, 284-285) for further discussion of 'captured' tunes. For the story of how this tune may have originated in the Mande heartland and been brought to (and captured by) Segu, see discussion of the 'river tune' in Durán (2007a).

30. It should be noted that there are other kinds of Bamana music which are not the domain of jeliw, such as bara drumming and dancing to the bara, a calabash drum, and balani (non-jeli xylophones). They overlap with jeli music in that they may also be perceived as 'warlike' (see Brandes and Malé et al. 1998, track 5), and may reference the Segu Empire, but their musicians do not recite the epic, which is always considered the work of the jeliw. All these different factors tend to cloud the perception of what actually constitutes Bamana jeli music. To complicate the issue, several well-known Malian 
'artistes' (a term used in Mali to describe non-jeli musicians) such as Amadou \& Mariam, Djeneba Seck, Rokia Traoré, and the late Lobi Traoré base their music on Bamana styles, but not the jeli repertoire, with its stories of Segu.

31. See Strawn (2011), the most detailed study to date of the music of Wasulu hunters.

32. To hear a recording of Prisoner's Talking Blues, go to http://www.youtube.com/watch?v=ZadLjj2KPmE (Accessed July 24, 2012). For more information on the artist and the album, see http://thedailyguru. blogspot.co.uk/2010/01/january-8-robert-pete-willams-prisoners.html (Accessed February 24, 2012).

33. For further information on this LP, see http://www.maliwatch.org/SOCIO-ECO/Hadi/Recital Dah Monzon.htm (Accessed 10 March 2013).

34. Another version of 'Bambugu Nce' can be heard on Bassekou Kouyaté's album I speak fula, entitled 'Bambugu blues'. A faster version of this tune, renamed 'Cheikhna Demba', can be heard on the album New Ancient Strings (see Duran 2011), featuring kora duets. It was significantly adopted by ORTM (Mali's national television station) as their signature tune from c. 2000-2010.

35. Ensemble Instrumental National du Mali. LP recording, Kunkan Ko 77.44.11. Source: http://wrldsrv. blogspot.co.uk/search?q=ensemble+national (Accessed 30 December 2012).

36. Versions of this have been widely recorded, especially during the 1980 s and early 1990 s by popular jelimusow (female jelis) such as Ami Koita and Tata Bambo Kouyaté, to praise the Malian benefactor Babani Sissoko. See Schulz (2001, 150, 181), and Eyre (2000, 182-183).

37. See the transcription by Rosemary Bock in Conrad 1990; one of the few notations of a Bamana jeli tune, it is an accurate representation of the melody although it is usually played in $12 / 8$ not $4 / 4$ as transcribed here. An example of Bakari jan can be found on Segu Blue, track 4 'Juru nani' (see Duran 2007a).

38. See for example Le hoddu peul/the Fulani hoddu, compact disc (Ocora, 2006). See also Hawa Dramé's 'Mbaoudi' on her cassette, Syllart SYL 8384.

39. Ali Farka Touré, Red \& Green, two compact discs, World Circuit WCD 070. Spelling of the track is 'M'baudy'. Originally recorded at Radio Mali in 1988, re-released by World Circuit in 2004.

1460 40. Demba Fadiga - Camara Production présente Hommage Abrahima Diakite. Compact disc.

41. See Charry (2000a: Chapter 5) and Counsel (2009) for discussion of the modernization of Maninka music.

42. One of the few recordings of the post-independence years that specifically references the blues is the Guinean piece entitled 'Kadia Blues', which is in minor key and slow triple time. It was originally composed and recorded by the Guinean guitarist Kanté Facelli, and later immortalized by the dance band Kélétigui et ses Tambourinis. 'Kadia Blues' can be heard on the CD The Syliphone Years 1968-70 (Stern's African records). Kanté Facelli and his musical partner Keita Fodéba were, incidentally, very influential guitarists in the region; Ali Farka Touré cites Keita Fodéba as the first guitarist he ever heard, and it could be that some of Touré's initial ideas about the blues came from here.

43. For example, Heather Maxwell notes that the music of Wasulu - which is pentatonic - is 'just a small part of a larger genre of popular song that is only different in terms of its distinction from jeliya, which uses a heptatonic mode' (Maxwell 2002, 157; my italics).

1470 44. Cf. the music of hunters' associations in southern Mali which is also considered to be cèfoli (Strawn 2011, 51).

45. At the time of writing, in March 2013, there is however no clear indication of how recent political events in Mali will affect the once vibrant music scene in the country.

46. See Bird $(1999,284)$. The non-enslavement of jeliw has been cited to me by virtually every jeli I have spoken to.

1475 47. See for example the playing technique of DiaDia Fadiga and his ensemble, http://www.youtube.com/

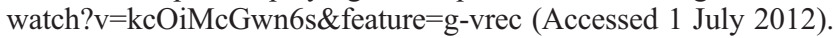

48. This is my translation from Kesteloot's French (no Bamana version of the epic is supplied), where the term 'guitars' is used, but 'guitar' has been used as a synonym for the ngòni by many authors including Frobenius (1921), so it seems appropriate to reinstate the indigenous term 'ngòni'.

49. Tayiru Banbera accompanied himself on the ngoni for the performances transcribed by Conrad (see Conrad 1990, 35), but when performing for Dumestre a decade earlier he was accompanied by another ngòni player called Biton (no surname given) (Dumestre 1979, 305).

50. During the making of the album Kulanjan with a group of Malian musicians including Bassekou Kouyaté, the African-American bluesman Taj Mahal stated 'all you do is take these melodies and make them fall a little differently, and you have the blues' (Taj Mahal, personal communication to the author in the studio while recording the album Kulanjan 1999). See sleeve notes to Taj Mahal \& Toumani Diabate: Kulanjan, compact disc, Hannibal HNCD 1444 (1999). 
51. Bassekou recited the three in Bamanan: $A$ be ni kènè wele (It recalls new life), $A$ be joli kènè wele (It recalls fresh blood), $A$ be bo kènè wele (It recalls fresh excrement). For discussion of 'Janjun', a song in the Maninka repertoire also considered ritual (see Charry 2000, 82-83).

52. It can be heard at http://wrldsrv.blogspot.co.uk/2010/01/old-lion.html.

53. It can be heard at http://www.youtube.com/watch?v=gbxcAi6T1yE.

54. See Durán $(1995,2000)$.

55. Bambara Blues was the title of one of Lobi Traoré's albums. Compact disc, Buda Records, 1999.

56. [1971] Musique du Mali. Volume 3. Banzoumana Sissòko. Le vieux lion. Volume 2. Bärenreiter-Musicaphon. BM 30 L 2553. LP disc. There are very few other recorded versions of 'Jonkoloni'. One listed as 'Djongloni' is by the female Bamana singer Koni Coumaré accompanied on ngòni, recorded in 1976. See http://www.radioafrica.com.au/Discographies/Malian.html (Accessed 15 July 2012).

Other versions include 'Ja dugu kolo ba' by Bamana singer and guitarist Bassi Kouyate, on his album entitled Mali: chants des griots bambara, and 'Jonkoloni' by Bassekou Kouyaté on Segu Blue (Durán 2007a).

57. I am grateful to Professor Owen Wright of SOAS University of London for translating the German into English. The source of the texts quoted below is Frobenius (1921, 106-110).

\section{References}

Ames, David. 1955. "Wolof Music of Senegal and The Gambia", Sleeve Notes, Long-Playing Discs Folkways FE 4462.

Arnoldi, Mary Jo. 1995. Playing With Time: Art and Performance in Central Mali. Bloomington/ Indianapolis: Indiana University Press.

Austen, Ralph, ed. 1999. In Search of Sunjata: The Mande Epic as History, Literature and Performance. Bloomington: Indiana University Press.

Bailleul, le Père Charles. 1996. Dictionnaire Bambara-Français. Bamako: Editions Donniya.

Ba Konare, Adam. 1987. "L'épopée de Segu. Da Monzon: un pouvoir geurrier." Pierre-Marcel Favre (collection Centre Europe-Tiers Monde), Paris and Lausanne.

Banbera, Tayiru. 1998. "Segu maana bamanankan na : Bamana language edition of the epic of Segu/according to Tayiru Banbera." Recorded and edited, with an introduction by David C. Conrad; transcribed and edited by Soumaila Diakite, Kassim Kone and Karim Traore. Madison: University of WisconsinMadison.

Belcher, Stephen. 1999. Epic Traditions of Africa. Bloomington Indiana: Indiana university Press.

Bird, Charles. 1972. "Bambara Oral Prose and Verse Narratives Collected by Charles Bird." In African Folklore, edited by Richard M. Dorson, 441-477. Indiana University Press.

Bird, Charles. 1999. "The Production and Reproduction of Sunjata." In Search of Sunjata: The Mande Epic as History, Literature and Performance, edited by Ralph Austen, 275-296. Bloomington: Indiana University Press.

Bock, Rosemary T. 1990. “The Music.” In A State of Intrigue: The Epic of Bamana Segu According to Tayiru Banbera, edited by David C. Conrad, 35-40. Oxford: Oxford University Press.

Brandes, Edda, and Salia Malé (recordings and sleeve notes). 1998. Mali: musique bambara du Baninko/ Bambara music of Baninko. Compact disc, AIMP LVIII. Musée d'Ethnographie: Geneva.

Brandes, Edda, and Salia Malé (recordings and sleeve notes). 2008. Mali: Peul - Fulbe. Compact disc, National Museum of Mali \& Ethnologisches Museum of Berlin.

Brett-Smith, Sarah C. 1994. The Making of Bamana Sculpture: Creativity and Gender. Cambridge: Cambridge University Press.

Camara, Sekou. 2002. "The dan: A Disappearing Musical Instrument", chapter 4 in Conrad, David C. Somono bala of the upper Niger, Leiden, Boston: Brill.

Carney, Judith Ann. 2001. Black Rice: African Origins of Rice Cultivation in the Americas. London: Harvard University Press.

Charry, Eric. 1994. "The Grand Mande Guitar Tradition of the Western Sahel and Savannah.” The World of Music 36 (2): 21-61.

Charry, Eric. 1996. "Plucked Lutes in West Africa: An Historical Overview." The Galpin Society Journal 49: 3-36.

Charry, Eric. 2000a. Mande Music: Traditional and Modern Music of the Maninka and Mandinka of West Africa. Chicago: University of Chicago Press.

Charry, Eric. 2000b. "Mamaya: Renewal and Tradition in Manninka Music of Kankan, Guinea (1935-45)." In The African Diaspora: A Musical Perspective, edited by Ingrid Monson, 187-206. 
Charry, Eric, Seydou Camara, and Jan Jansen. 2002. "The Mande Praise Song Kayra (Peace): Mande Global Perspectives." Metamorphoses: A Journal of Literary Translation 10 (1): 300-320.

Charters, Samuel. 1981. The Roots of the Blues: An African Search. Indiana: Indiana University.

Cisse, Youssou Tata, and Wa Kamissoko. 1988. La Grande geste du Mali: des origines a la fondation de l'empire. Bamako: Karthala-Arsan.

1535 Colleyn, Jean-Paul, and Catherine De Clippel. 1998. Bamanaya. Un' art di vivere in Mali/Bamanaya. Un art de vivre au Mali. Milano: Centro Studi Archeologica Africana.

Conrad, David C. 1990. A State of Intrigue: The Epic of Bamana Segu According to Tayiru Banbera. Oxford: Oxford University Press.

Conrad, David C. 1999. "Review of Colleyn, Jean-Paul \& De Clippel, Catherine." 1998. Bamanaya. Un' art di vivere in Mali/Bamanaya. Un art de vivre au Mali", Cahiers d'Études Africaines 39, 155-156, pp. 1001-1004.

1540 Conrad, David C., and Humphrey J. Fisher. 1983. "The Conquest that Never was: Ghana and the Almoravids, 1076. The Local Oral Sources." History in Africa 10: 53-78.

Conrad, David, and Barbara Frank. 1995. Status and Identity in West Africa: Nyamakalaw of Mande. Bloomington: Indiana University Press.

Coolen, Michael Theodore. 1982. "The Fodet: A Senegambian Origin for the Blues?” The Black Perspective in Music 10 (1): 69-84.

Coolen, Michael Theodore. 1984. "Senegambian Archetypes for the American Folk Banjo." Western Folklore 43 (2): 117-132.

Coolen, Michael Theodore. 1991. "Senegambian Influences on Afro-American Musical Culture." Black Music Research Journal 11 (1): 1-18.

Couloubaly, Pascal Baba F. 1990. Une Société rurale Bambara a travers des chants de femmes. Ifan-Dakar: University Cheick Anta Diop.

Couloubaly, Pascal Baba F. 1993. "The Narrative Genre among the Bamana of Mali." Research in African Literatures 24 (2): 47-60.

Counsel, Graeme. 2009. Mande Popular Music and Cultural Policies in West Africa: Griots and Government Policy Since Independence. Saabrucken: VDM Verlag.

Courlander, Harold, and Ousmane Sako. 1982. The Heart of the Ngoni: Heroes of the African Kingdom of Segu. New York: Crown Publishers.

Diallo, Mamadou. 1988. Esssai sur la musique traditionnelle au Mali. France: ACCT.

Diarra, Bakary. 2003. Poesie epique et lyrique royaume bamanan de Segou. Bamako: MaliSoro print color.

Diawara, Mamadou. 1996. "Le griot mande a l'heure de la globalisation." Cahiers d'Études Africaines 144 (XXXVI-4): 591-612.

Diawara, Mamadou. 1997. "Mande Oral Popular Culture Revisited by the Electronic Media." In Readings in African Popular Culture, edited by Karin Barber, 40-47. London: International African Institute.

Djata, Sundiata A. 1997. The Bamana Empire by the Niger: Kingdom, Jihad and Colonization 1712-1920. Princeton: Markus Wiener Publishers.

1560 Dumestre, Gérard. 1979. La geste de Ségou, racontée par des griots bambara, traduite et édité par Gérard Dumestre. Paris: Armand Colin.

Durán, Lucy. 1981a. "A Preliminary Study of the Wolof Xalam (with a list of recordings at the BIRS)." Recorded Sound LXXIX: 29-50.

Durán, Lucy. 1981b. "Theme and Variation in Kora Music: A Preliminary Study of 'Tutu Jara' as Performed by Amadu Bansang Jobate." In Music and Tradition: Essays on Asian and Other Musics Presented to Laurence Picken, edited by D. R. Widdess and R. F. Wolpert, 183-196. Cambridge: Cambridge University Press.

Durán, Lucy. 1995. "Birds of Wasulu: Freedom of Expression and Expressions of Freedom in the Popular Music of Southern Mali." British Journal of Ethnomusicology 4: 101-134.

Durán, Lucy. 1996. (author of sleeve notes). Ali Farka Toure - Radio Mali. Compact disc, World Circuit WCD044.

Durán, Lucy. 2000. "Women, Music, and the Mystique of Hunters in Mali." In The African Diaspora: A Musical Perspective, edited by Ingrid Monson, 137-186. Garland: New York.

Durán, Lucy. 2007a. (producer; author of sleeve notes). Segu Blue. Compact disc, featuring Bassekou Kouyaté and Ngoniba, OutHere Records OH007.

Durán, Lucy. 2007b. "Ngaraya - Women and Musical Mastery in Mali." Bulletin of SOAS 70 (3): 569-602.

Durán, Lucy. 2009. (co-producer; author of sleeve notes). I speak fula. Compact disc, featuring Bassekou Kouyaté and Ngoniba, OutHere Records OH013. 
Durán, Lucy. 2011. "Music Production as Tool of Research, and Impact.” Ethnomusicology Forum 20 (2): 229-232.

Durán, Lucy. 2013. Director and camera. Growing into Music, Mali 1. Da kali: the pledge to the art of the griot, and Growing into Music, Mali 2. Do farala a kan: something has been added. Musical progress amongst children of griot families. DVD, SOAS, University of London. https: www. growingintomusic.co.uk.

Eltis, David, Philip Morgan, and David Richardson. 2007. "Agency and Diaspora in Atlantic History: Reassessing the African Contribution to Rice Cultivation in the Americas." The American Historical Review 112 (5): 1329-1358.

Epstein, Dena. 1975. “The Folk Banjo: A Documentary History.” Ethnomusicology 19 (3): 347-371.

Epstein, Dena. 1977. Sinful Tunes and Spirituals: Black folk Music to the Civil War. University of Illinois Press.

Eyre, Banning. 2000. In Griot Time: An American Guitarist in Mali. Philadelphia: Temple University Press.

Frank, Barbara. 1995. "Soninke garankéw and Bamana-Malinké jeliw: Mande Leatherworkers, Identity, and the Diaspora." In Status and Identity in West Africa: Nyamakalaw of Mande, edited by David Conrad and Barbara Frank, 133-150. Bloomington: Indiana University Press.

Frank, Barbara. 1998. Mande Potters \& Leather-workers: Art and Heritage in West Africa. London: Smithsonian Institution Press.

Frobenius, Leo. 1921. Atlantis bd.6. Spielmannsgeschichten der Sahel. Iena, Eugen Diederich. Reprint Martin Sändig.

Frobenius, Leo. 1925. Dichten und Denken im Sudan. Atlantis V. Iena, Eugen Diederichs.

Ganay, Solange de. 1995. Le sanctuaire Kama blon de Kangaba: histoire, myths, peintures parietales et ceremonies septennales. Paris: Karthala.

Gibbal, Jean-Marie. 1993. Genii of the River Niger. Chicago: Chicago University Press.

Gilroy, Paul. 1993. The Black Atlantic: Modernity and Double Consciousness. Cambridge: Harvard University Press.

Hale, Thomas. 1998. Griots and Griottes: Masters of Words and Music. Bloomington: Indiana University Press.

Impey, Angela. 2008. "Sound, Memory and Dis/placement: Exploring Sound, Song and Performance as Oral History in the Southern African Borderlands." Oral History 36 (1): 33-44.

Jansen, Jan. 1999. "An Ethnography of the Epic of Sunjata in Kela." In Search of Sunjata: The Mande Epic as History, Literature and Performance, edited by Ralph Austen, 297-311. Bloomington: Indiana University Press.

Janson, Marloes. 2002. The Best Hand is the Hand that Always Gives: Griottes and their Profession in Eastern Gambia. Leiden: Research School CNWS.

Johnson, John W., Thomas A. Hale, and Stephen Belcher, eds. 1997. Oral Epics From Africa: Vibrant Voices From a Vast Continent. Bloomington/ Indianapolis: Indiana University Press.

Keita, Cheick M. Chérif 1995. "Jaliya in the Modern World: A Tribute to Banzumana Sissoko and Massa Makan Diabate." In Status and Identity in West Africa: Nyamakalaw of Mande, edited by David Conrad and Barbara Frank, 182-196. Bloomington: Indiana University Press.

Kesteloot, Lilyan. 1993. L'epopee Bambara de Segou. Tome 1, avec la collaboration de Amadou Traore \& Jean-Baptiste Traore. Paris: Harmattan.

Kesteloot, Lilyan, ed. and trans. 1993. Da Monzon de Segou. Paris: L'Harmattan, 1993. 2 vols. First published 1974, Paris. Fernand Nathan.

Kesteloot, Lilyan, and Gérard Dumestre. 1975. La prise de Dionkoloni. Episode de l'épopée bambara raconté par Sissoko Kabiné, recueilli para Lilyan Kesteloot, édité par Gérard Dumestre et lilyan Kesteloot avec la collaboration de J.-B. Traoré. Paris: Armand Colin.

Knight, Roderic C. 1972. Kora Manding: Mandinka music of The Gambia, sleeve notes, Ethnodisc recordings, Tucson: Pachart publishing.

Knight, Roderic C. 1973. "Mandinka Jaliya: Professional Music of the Gambia." PhD thesis., UCLA.

Kone, Kassim. 2000. "The Peoples of the Middle Niger: The Island of Gold." (book review) American Anthropologist 102 (3): 636-637.

Kubik, Gerhard. 1999. Africa and the Blues. Jackson: University Press of Mississippi.

Loncke, Sandrine (recordings and author of sleeve notes). 1997. Burkina Faso, the voice of the Fulbe, Collection du Centre National de la Recherche Scientifique et du Musée de l'Homme. Compact disc, Le Chant du Monde CNR 2741079. 
MacDonald, K., et al. "Sorotomo: a forgotten Malian Capital?.” Archaeology International, [S.1.], p. 52-64, oct. 2011. ISSN 2048-4194. Accessed March 30, 2013. http://www.aijournal.com/article/view/ai. $1315 / 71$.

Maxwell, Heather A. 2002. "Destiny's Divas: Wassolu Singing, Music Ideologies, and the Politics of Performance in Bamako." Mali. PhD thesis., Bloomington, Indiana University.

Mazzoleni, Florent. 2011. Musiques modernes et traditionneles du Mali. Pantin, France: Le Castor astral.

McNaughton, Patrick. 1988. The Mande Blacksmiths: Knowledge, Power, and Art in West Africa. Bloomington: Indiana University Press.

McNaughton, Patrick. 2008. A Bird Dance Near Saturday City: Sidi Ballo and the Art of West African Masquerade. Bloomington Indiana: Indiana University Press.

Meillassoux, Claude. 1968. Urbanization of an African Community: Voluntary Associations in Bamako. Seattle/London: University of Washington Press.

Meillassoux, Claude. 1991. The Anthropology of Slavery: The Womb of Iron and Gold. Chicago: Athlone Press.

Meintjes, Louise. 2003. Sound of Africa! Making Music Zulu in a South African Studio. London: Duke University Press.

Monteil, Charles. 1977. Les Bambara de Segou et du Kaarta. Paris, Maisonneuve et Larose. 1977. First printed 1924. Notes by Jean Bazin.

Newton, Robert C. 1999. "Out of Print: The Epic Cassette as Intervention, Reinvention and Commodity." In In Search of Sunjata: The Mande Epic as History, Literature and Performance, edited by Ralph Frank, 313-327. Bloomington: Indiana University Press.

Oliver, Paul. 1970. Savannah Syncopators: African Retentions in the Blues. New York: Stein \& Day.

Oliver, Paul. 1982. “"Twixt Midnight and Day: Binarism, Blues, and Black Culture.” Popular Music 2: 179_ 200.

Pageard, Robert. N.d. Notes sur l'histoire des Bambara de Ségou. Published by author.

Park, Mungo. 1799/1983. Travels into the Interior of Africa. London: Eland.

Roberts, Richard L. 1987. Warriors, Merchants, and Slaves: The State and the Economy in the Middle Niger Valley, 1700-1914. Stanford: Stanford University Press.

Sauvageot, Serge. 1965. "Contribution a l'histoire du royaume bambara de Segou (XVIIIe et XIXe siecle)." Doctor d'état thesis.,Paris, University of Sorbonne.

Schulz, Dorothea E. 2001. Perpetuating the politics of praise: jeli singers, radios, and political mediation in MaliStudien zur Kulturkunde no. 118. Koln: Rudiger Koppe Verlag.

Strawn, Cullen. 2011. "Kunfe Ko: Experiencing Uncertainty in Malian Wasulu hunters" Music Performance and Hunting." $\mathrm{PhD}$., Indiana University.

Tamari, Tal. 2007. "'Hady': A Traditional Bard's Praise Song for an Urban Teenager." Research in African Literatures 38 (3): 77-111.

Taylor, F. W. 1995. Fulani-English Dictionary. New York: Hippocrene Books.

Vydrine, Valentin. 1999. Manding-English Dictionary (Maninka, Bamana). Vol. 1, St Petersburg: Dimitry Bulanin Publishing House.

Zahan, Dominique. 1974. The Bambara. Leiden: Brill. 